\title{
Review
}

\section{How to Assess the Measurement Performance of Mobile/Wearable Point-of-Care Testing Devices? A Systematic Review Addressing Sweat Analysis}

\author{
Sarah Tonello ${ }^{1, *(\mathbb{D})}$, Giulia Abate ${ }^{2}(\mathbb{D})$, Michela Borghetti ${ }^{3}\left(\mathbb{D}\right.$, Nicola Francesco Lopomo $^{3}\left(\mathbb{C}\right.$, Mauro Serpelloni $^{3} \mathbb{C}$ \\ and Emilio Sardini ${ }^{3}$ (D) \\ 1 Department of Information Engineering, University of Padova, 35131 Padova, Italy \\ 2 Department of Molecular and Translational Medicine, University of Brescia, 25123 Brescia, Italy; \\ giulia.abate@unibs.it \\ 3 Department of Information Engineering, University of Brescia, 25123 Brescia, Italy; \\ michela.borghetti@unibs.it (M.B.); nicola.lopomo@unibs.it (N.F.L.); mauro.serpelloni@unibs.it (M.S.); \\ emilio.sardini@unibs.it (E.S.) \\ * Correspondence: sarah.tonello@unipd.it
}

check for

updates

Citation: Tonello, S.; Abate, G.;

Borghetti, M.; Lopomo, N.F.;

Serpelloni, M.; Sardini, E. How to

Assess the Measurement

Performance of Mobile/Wearable

Point-of-Care Testing Devices? A

Systematic Review Addressing Sweat

Analysis. Electronics 2022, 11, 761 .

https://doi.org/10.3390/

electronics11050761

Academic Editor: Ajeet Kaushik

Received: 31 January 2022

Accepted: 25 February 2022

Published: 1 March 2022

Publisher's Note: MDPI stays neutral with regard to jurisdictional claims in published maps and institutional affiliations.

Copyright: (C) 2022 by the authors. Licensee MDPI, Basel, Switzerland. This article is an open access article distributed under the terms and conditions of the Creative Commons Attribution (CC BY) license (https:// creativecommons.org/licenses/by/ $4.0 /)$.

\begin{abstract}
Recent advances in technologies for biosensor integration in mobile or wearable devices have highlighted the need for the definition of proper validation procedures and technical standards that enable testing, verification and validation of the overall performance of these solutions. Thus, reliable assessment-in terms of limits of detection/quantitation, linearity, range, analytical and diagnostic sensitivity/specificity, accuracy, repeatability, reproducibility, cross-reactivity, diagnostic efficiency, and positive/negative prediction-still represents the most critical and challenging aspect required to progress beyond the status of feasibility studies. Considering this picture, this work aims to review and discuss the literature referring to the available methods and criteria reported in the assessment of the performance of point-of-care testing (PoCT) devices within their specific applications. In particular, without losing generality, we focused on mobile or wearable systems able to analyze human sweat. In performing this review, the focus was on the main challenges and trends underlined in the literature, in order to provide specific hints that can be used to set shared procedures and improve the overall reliability of the identified solutions, addressing the importance of sample management, the sensing components, and the electronics. This review can contribute to supporting an effective validation of mobile or wearable PoCT devices and thus to spreading the use of reliable approaches outside hospitals and clinical laboratories.
\end{abstract}

Keywords: biosensors; point-of-care testing device; mobile; wearable; validation procedures; sweat

\section{Introduction}

Recent advances in nanotechnologies, microfluidics, printed electronics, additive manufacturing, and biomaterials have brought about a significant improvement in the integration of sensing elements within wearable devices for point-of-care testing (PoCT) applications [1]. These technological evolutions contributed to the design of complete integrated systems, including not only the specific biosensing components but also the sample treatment and distribution solutions, and the overall electronics [2]. This efficient integration allows these devices to work in a standalone modality and perform all the steps required to obtain a reliable detection of specific analytes, including sample collection and result interpretation [3]. This novel and continuously evolving approach appears to be particularly promising for on-site and (almost) real-time feedback on various biomarkersi.e., any measurable indicator related to the health status of a subject-via non-invasive approaches. One of the main advantages of this method is the possibility of performing all these analyses without the necessity of accessing health facilities and to promote homebased and decentralized modalities [4]. Of course, several requirements, related to both 
the functions and applications, need to be satisfied in order to make these tools a solid and reliable method accepted by both the medical-scientific community and end users [5]. In particular:

- Optimal levels of specificity and sensitivity are needed for the early detection of specific disease-related markers [6].

- Repeatability and reproducibility of the methods can ensure reliable results, which must be strictly non-dependent on users/testers or the environmental conditions.

- Stability over time is required to ensure reliable outcomes even when multiple tests need to be performed across a long span of years, as happens, for example, in the monitoring of chronic pathologies.

- Usability aspects (e.g., invasiveness and complexity of the procedures for sample extraction and preparation, user interface, etc.) must be addressed to ensure a wide acceptance of the technology, and also the overall direct and indirect costs of the proposed solutions, which can be assessed in terms of general cost-effectiveness.

In the last decade, in order to develop specific PoCT solutions, several approaches have been investigated in terms of detection principles. These can be grouped into three main categories: (1) mass-based, (2) optical and (3) electrochemical biosensors. Even though mass-based and optical biosensors present high levels of sensitivity and specificity $[7,8]$, both show significant challenges in terms of lack of repeatability, high dependency upon contour variables, high cost, excessive fragility, limited flexibility, reduced portability, and low integrability of the readout units [9]. On the contrary, electrochemical biosensors represent the easiest solution to fabricate and miniaturize, thus facilitating the possibility to integrate the customized readout circuits on the same sensing substrate [10]. Therefore, aiming towards large scale and low cost diagnostic solutions, the potential to integrate electrochemical biosensors in modular PoCT or lab-on-a-chip systems represents an extremely promising strategy in terms of impact [11], even when compared to the bulkier and more expensive optical and mass-based approaches [12,13].

Indeed, the recent advances in the area of printing technologies combined with the progress in bio- and electro-chemistry [14], nanostructures [15], solid-state and surface materials, integrated circuit electronics, microfluidics, and data processing have raised the possibility to design and develop a whole new generation of electrochemical biosensors [16]

Regardless of the chosen technology, it will be essential to pay close attention to the validation of the inherent metrological performance of each system in its entirety, including both the sample management, the sensing components, and the overall electronic design [1]. Thus, although recent advances in nanostructures, nano-printing strategies and hybrid nano-molecules have strongly improved the limit of detection (LoD) of specific biomarkers, the main overall challenges of PoCTs still concern selectivity, repeatability, and stability [17]. These characteristics need to be validated through standard procedures before the whole system can be considered valuable for applications.

Keeping in mind all those requirements, the validation procedures-including both the laboratory and clinical tests required to assess their overall metrological performancesrepresent the most crucial aspect in the design and development of PoCT solutions. From this perspective, a broad classification of PoCT systems can be made, distinguishing between qualitative/semi-quantitative solutions, devices able to provide a binary (yes/no) answer, and quantitative technologies, which associate a quantitative output with the performed analysis. Among these latter, the validation of quantitative electrochemical PoCT systems is the most articulated process, and often there are no standardized or commonly accepted procedures able to assess the overall validity of the novel devices in comparison to well-established lab methodologies.

This review aims to provide a deep insight into the main validation procedures adopted to assess the metrological characteristics of electrochemical PoCT systems. Further, this review is mainly focused on human sweat biofluid to highlight the importance of the non-invasiveness of this approach without losing generality. 


\section{Search Strategy and Papers Selection}

The review took into consideration original studies identified on three different online databases (Scopus, Web of Science, and Pubmed) and published from 2010 to 2021. The search was performed on title, abstract, and keyword by using the following string:

(sweat) AND (validation OR accuracy OR performance OR precision OR sensitivity OR specificity OR assessment OR reliability OR repeatability OR error OR uncertainty OR "limit of detection") AND electrochemic * AND (biosensor * OR sensor * OR test * OR instrument * OR technolog * OR method * OR equipment *).

Conference and review papers were excluded. A first title screening was then performed to exclude all papers focused only on materials, techniques or addressing electrochemistry rather than on a complete description of the development of wearable PoCT devices and their validation. Finally, articles selected for this review study were included only if (1) evaluating sweat as biofluid, (2) including both in vitro and in vivo validation stages, and (3) providing sufficient information about the customized electronics integrated into the mobile or wearable device. All papers that characterized the overall sensing platforms with a commercial potentiostat (such as $[18,19])$ ), or consisting of commercial sensors (such as [20]), or that failed to include a description of the customized electronics used were excluded (such as [21]). For example, in [22,23] the biodevices were validated only in vivo whereas in vitro validation tests of those devices were not reported in previous papers; instead in $[24,25]$, the biodevices were tested only in vitro and by using the enzyme prepared in artificial solutions.

The whole screening and inclusion/exclusion process was performed by using an online tool for systematic review [26].

Included papers were analyzed and the following details were extracted, compared discussed through the text and summarized in the cumulative tables reported at the end of the paper. Particular attention was given to:

- Application and type of transducing principle: target analyte, transducing principle (amperometric, impedimetric, or potentiometric), and detection protocol (Table 1).

- $\quad$ Sensing (Table 2).

- Validation protocols:

- In-laboratory validation (with standard solutions or artificial biofluid) (Table 3).

$\bigcirc \quad$ On-body validation or clinical trials, comparison with gold standard analytical techniques (Table 4).

- Electronics design (Table 5).

- Adopted metrological figures, including sensitivity, limit of detection, accuracy, selectivity, repeatability, reproducibility, stability, linear range, response time, and recovery values (Table 6).

The literature research identified 255 papers published from 2010 to 2021 according to the string used as reported above. After carefully checking, conference papers and review articles were excluded from the analysis (51), further manuscripts focused on novel materials characterization or without metrological information reported in abstract with base research application (84) were excluded. After this first article selection, we had identified a panel of 120 manuscripts well characterized from a metrological point of view but among them only a few also reported on-body testing. Thus, 15 manuscripts were finally identified as the most representative to discuss validation procedures and technical standards for practical on-body testing for use in the near future. Based on in-depth analysis of those papers, the following sections address the most relevant standard parameters for validation, the validation procedures and the electronic design considerations. Finally, an overall discussion is provided on the main opportunities and challenges highlighted in the comparative analysis. 


\section{Standard Parameters for Validation}

The performed review of scientific literature allowed identifying the main metrics that are used to validate the mobile or wearable PoCT devices.

\subsection{Sensitivity}

The sensitivity in electrochemical biosensors often refers to the slope of the calibration curve obtained by measuring the response of the sensor at different concentrations of the target analyte. It is usually expressed as the ratio between an electrical parameter and the analyte concentration, and it is one of the most relevant indicators of the performance of the biosensor. As the sensitivity increases, the ability to differentiate among very similar concentrations increases. Since one of the main issues in electrochemistry is unspecific binding, to guarantee optimal performance and the possibility of detecting low concentrations of analytes, high specificity should be combined with a limited signal derived from the background noise sample (blank or matrix sample) and low intrinsic variability of the sensing device with respect to the blank sample.

\subsection{Limit of Detection and Limit of Quantification}

The limit of detection, often referred to as LOD or LLOD (lower limit of detection), represents one of the most adopted quantities to characterize the performance of a biosensor and compares outputs among different solutions. LOD expresses the lowest quantity of target analyte that can be distinguished from the absence of that substance (a blank value) with a stated confidence level (generally $99 \%$ ). It is estimated from the mean of the blank, the standard deviation (SD) of the blank, the slope (analytical sensitivity) of the calibration plot, and a defined confidence factor (usually 3SD) $[27,28]$. It can be also considered an indicator of the resolution of the system obtained with a statistical approach since it takes into consideration the contributions of both uncertainty and resolution [27]. Together with the LOD or LLOD, which look at the smallest detectable quantity, the upper limit of detection (ULOD) is often considered, looking at the greatest quantity that can be quantified. This is useful in particular for those biosensors involving selective membranes or enzymes that can become saturated above a certain concentration of analyte [29]. Another metrological parameter that can be associated with the LOD is the limit of quantification (LOQ), which is useful whenever the testing environment may lead to poor reliability due to the significant influence of surrounding variables. The LOQ is usually computed following the same protocol but using a simple "rule of thumb", such as ten times the SD [30] or three times the LOD [27].

\subsection{Error Analysis and Accuracy}

Accuracy in a biosensor is computed as the maximum divergence from the most reliable "gold standard" in terms of assay output. It is usually expressed as a percentage of error of the output from the validated biosensor with respect to the output of traditionally accepted laboratory equipment. For example, $\mathrm{pH}$ measurement accuracy is often provided according to $\mathrm{pH}$-meter output, flow rate measurement accuracy is provided according to optical measurement [31], while the gold standards for ion quantification are typically atomic absorption spectrophotometer (AAS) and ion chromatography (IC) [29]. Further, results from biosensors for metabolites such as glucose or lactate are usually compared with the outputs from commercially available strips [32], and the results of alcohol quantification are compared with a commercial FDA-approved breath analyzer [32]. This comparison is a fundamental step for validating and confirming the reliability of a new method, taking as reference already commercialized technologies.

\subsection{Selectivity}

Selectivity represents the ability of the biosensor to correlate changes to a specific analyte, reducing the cross-sensitivity, thus detecting a given analyte in a sample containing a mixture of other analytes and contaminants. 
An ideal biosensor should present an output variation only in response to a variation in target analyte concentration, while no output variation should be detected for a change in any interfering substance. Therefore, the selectivity of a specific biosensor can be quantitatively expressed simply as a dimensionless scalar number, usually a percentage referring to the variation in the output when an interferent is added to a target analyte solution in equilibrium condition. Its quantification is useful to compare different sensors and different interfering effects, as can be found in [33], where the authors computed the percentage by which the variability in sensor response falls due to potential interferents or, as described in terms of cross-sensitivity, as the slope of the calibration curve when the biosensor is subjected to different concentrations of an interferent [34]. Often selectivity can be considered qualitatively good when no interfering peaks or additional contributions in the output are recorded in the presence of interfering analytes [35].

\subsection{Repeatability and Reproducibility}

Repeatability and reproducibility represent relevant parameters to characterize the performance of biosensors since they take into consideration the variability associated with the measurements, intrinsic due to fabrication variability or extrinsic due to variability in the measurement protocol. They are both usually expressed as percentage relative standard deviation with respect to average measurements.

Repeatability is the ability to respond with limited variability when identical input stimuli are applied under the same working conditions and measurement setup. Specific protocols for evaluating repeatability need to take into account modifications introduced in transducer properties during each measurement, thus applying a suitable protocol to restore the same condition before starting each measurement used to calculate repeatability [36,37].

Reproducibility refers to the ability to respond with limited variability when the same input stimuli are applied under different working conditions (different operators, different instrumentations, different setups).

During the biosensor validation phase, repeatability is the most frequently evaluated parameter since repeated measurements with the same instrumentation are performed on the same sensors or sensors from the same batch treated with the same functionalization protocol. When replicated measurements require a duplicated experimental setup then it is more correct to refer to reproducibility. This is the case, for example, when sensors are integrated into a paper-based or microfluidic setup. When two measurements are performed using the same sensors integrated into different setups, the variability among them, indicated in terms of standard deviation, is referred to as reproducibility. In other cases, repeatability refers to measurements made with a single biodevice, using a solution with the same analyte concentration, while reproducibility refers to the measurements provided by different sensors, such as in [38].

The main disadvantage of using poorly reproducible sensors is that they need to be frequently re-calibrated. Calibration is a necessary procedure that allows one to compensate for sensor-to-sensor fabrication variations, thus improving the accuracy of the sensors, and for sensor drift, mainly due to the instability of sensors. Calibration represents one of the main problems limiting the use of biosensors. Therefore, the information concerning the calibration of a given wearable biosensor should be specified in the biosensor datasheet.

\subsection{Stability}

Stability represents the degree of susceptibility to environmental disturbances and other factors that could take place in and/or around the biosensing system. The output of an unstable biosensor typically presents a drift that affects the quality of the measurement information. Stability is an important parameter when the sensor is applied in applications involving a continuous monitoring of the measurand. Two different approaches can be used to evaluate stability in biosensors for wearable devices. The first approach is to evaluate the stability of the biosensor when it is undergoing a continuous, long, and constant stimulus (e.g., a fixed analyte concentration). The second approach is to perform 
discrete measurements of the same sample concentration at specific time points. In both cases, stability outcome can be quantified by computing the maximum difference between starting and ending response of the sensor (absolute or as a percentage of the initial measurement) [32], or by computing the decreasing or increasing rate expressed as electrical quantity variation per unit of time [29].

In more detail, depending on the considered time period, the concept of "stability" can refer to (1) operational stability or (2) shelf/storage stability. In general, operational stability is evaluated over short periods of time-typically hours-so as to estimate the changes that might take place during a single phase of continuous measurement. Shelf/storage stability is evaluated over longer time periods-typically months-during which periodically repeated measurements are performed to check any possible change in the quantitative outcomes [39].

\subsection{Linear Working Range and Linearity}

Together with LOD and sensitivity, further relevant parameters that are extracted from the calibration curve are the limits of the linear working range and the linearity of the curve within those limits.

The definition of the linear working range consists in defining the lower and the upper concentrations of the analyte in which the calibration curve can be considered linear. Linearity is a quantitative indicator that defines how much the real curve differs from the ideal regression line. It is usually expressed as R-square [29]. The linear range might be strongly affected by the medium in which the target analyte is dissolved, therefore different results might be obtained from calibrations performed in standard solution with respect to those performed in artificial or real biofluid containing interfering molecules.

\subsection{Response Time}

The response time is a quantitative indicator of the time needed by the biosensor to provide an output that can be reliably correlated with the concentration of the analyte tested. It is usually computed thanks to a dynamic calibration, evaluating the time needed from the output to reach a fixed percentage of the maximum steady-state values. For traditional sensors, the response time is usually the time needed to go from 10 to $90 \%$ of the steady-state value, while for biosensor validation, high variability in the meaning of response time can be found. In some cases, as in [29], the response time to the electrolyte in potentiometric sensors is calculated from the in vitro calibration, as the time needed to go from the steady-state baseline value at the lowest concentration to the steady-state value of the concentration after a standard addition. In other cases, as in [31], the response time calculated from both in vitro and in vivo measurements is considered as the time between the injection of the target analyte and the moment in which the signal starts to rise or fall, changing from the steady-state in which it was before. In [38], since the biosensor was characterized according to the amperometric response, the times elapsed in different conditions were evaluated: (1) the time for the baseline stabilization, (2) the time for the signal appearance after the injection of the analyte, and (3) the time to reach the steady-state condition. This analysis allowed the determination of the minimum time for the best correlation between the analyte concentration and the biodevice output.

\subsection{Recovery Values}

Considering the in vitro validation of electrochemical sensors, another important metrological parameter is the recovery rate. This metric is usually obtained when a known amount of the target analyte is spiked into a sample matrix and then measured with the novel technologies, then, the variation between the measured concentration and the known value is calculated [40]. A bad outcome of the test suggests that the measure is affected by the matrix effect that occurs when there are differences between the sample matrix and calibrator diluent that affects the response in the signal [41]. 


\section{Validation Procedures}

A further important step in the definition of the correct assessment standards is to highlight the possible validation procedures used in the context of PoCT devices, visually summarized in Figure 1.

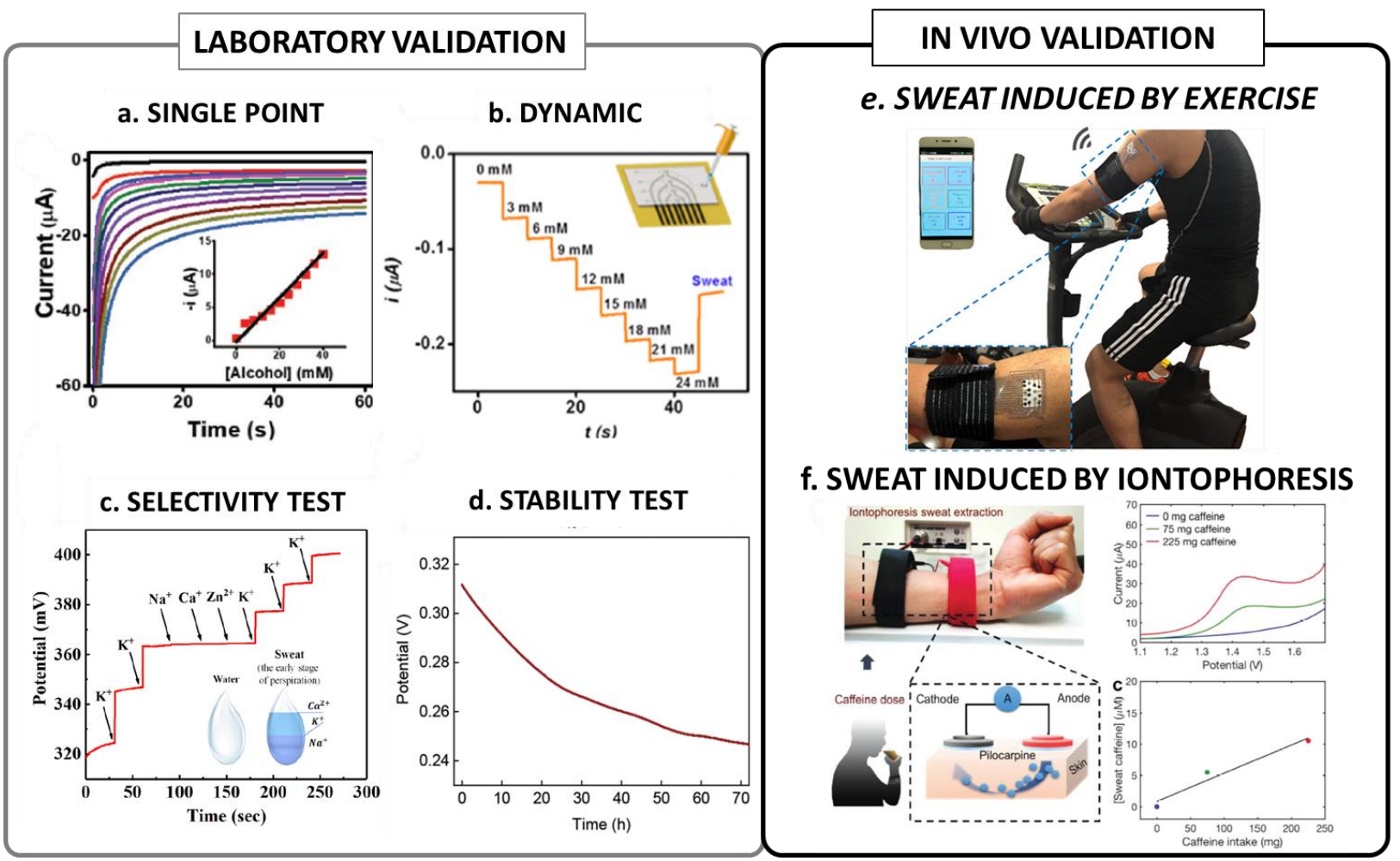

Figure 1. Summary of the most significant validation procedures of wearable sensors: (a) example of a single point chronoamperometric calibration reproduced from [32] (open access); (b) example of a dynamic chronoamperometric measurement of glucose, reproduced with permission from [42] Copyright 2021 American Chemical Society; (c) example of a standard selectivity test for $\mathrm{K}^{+}$potentiometric sensor reproduced with permission from [43], copyright 2020 Elsevier; (d) example of an operation stability test, reproduced with permission from [29] copyright 2020 Elsevier; (e) example of a typical setup for an exercise-induced sweat test, reproduced from [44] (open access); (f) example of a typical setup for a iontophoresis-induced test, reproduced with permission from [33], copyright 2018 WILEY-VCH Verlag GmbH \& Co. KGaA, Weinheim.

\subsection{Laboratory Validation}

The first stage of validation of any point of care refers to the analysis of the results obtained for the biosensor in controlled-environment laboratory conditions. Since in this phase the aim is not to characterize the complete PoCT device during its real use, portability is not required, and thus certified commercial instrumentation which serves as "gold standard" is often exploited to guarantee optimal accuracy, stability, resolution, and reproducibility of the measurement system. Moreover, these results are usually used as a reference comparison to validate any customized mobile or wearable electronic solution, and thus to ensure the reliability of in vivo [38] measurements. This phase is fundamental for optimizing the detection protocol, without taking into consideration further variability introduced by an on-body or a home-based use of the complete PoCT device. All the information acquired from the analyzed papers and concerning these approaches is summarized in Table 3. Furthermore, in the laboratory evaluation, all the issues about interferents need to be completely characterized in order to provide a controlled analysis of the effect of non-target analytes on the final output. The two main classes of laboratory validation are standard solution-based and artificial biofluid-based. 


\subsubsection{Validation Tests with Standard Solutions}

The first stage to validate any electrochemical sensors included in wearable devices encompasses evaluation of the performance performing an in vitro calibration using standard solutions prepared in a controlled environment, containing only the target analyte, without any interfering agents.

The ranges of concentration used to perform sensor calibration depend on the specific target analyte's physiological concentration expected during real operation. Focusing on validation of sensors for sweat analysis, standard solutions are usually obtained using deionized water to dilute electrolytes $[29,31]$ or a diluting buffer containing a supporting electrolyte as phosphate-buffered saline (PBS) [32], potassium chloride [35], or acetate buffer [33]. The choice of the most suitable solvent depends mainly on three factors: the solubility of the analyte, the window voltages of interest to detect the analyte, and the material of the working and counter electrodes. Thus, a suitable solvent should ensure no response in the potential window tested, to avoid interfering signals in the baseline. The window potential in which this takes place is named the "stability window" and its definition represents one of the most crucial operations to establish the most suitable supporting electrolyte solution and to ensure the reliability of any signal recorded when the analyte is present.

Usually, two different protocols are employed to evaluate and calibrate the sensor response under analyte concentration changes. The first protocol refers to a standard calibration, often known as "single point" or "static" calibration, in which several sensors equal to the number of tested concentrations are employed to build a calibration curve. Each sensor is exposed to a specific concentration and its electrical response related to the value of concentration tested, in terms of potential or current [33]. If several sensors are tested with the same concentration, the standard deviation of each calibration point can be calculated, providing a quantitative idea of the reproducibility of the measurement. The resulting calibration plot correlates the analyte concentration and the electrical response of the sensor, and provides quantitative information in terms of sensitivity, LOD, LOQ, and RSD.

The second protocol, also known as "continuous" or "dynamic" calibration, refers to a calibration in which the same sensor is successively exposed to different steps of rising and falling concentration of the target analyte, and its electrical output quantity measured. Knowing exactly the time in which the concentration is changed, from the measured output signal it is possible to extract useful information concerning the response time, the transitory, and the steady-state duration. The value reached by the electrical output during the steady state before each successive injection is sampled and related to the corresponding concentration. Thus, a calibration curve can be extracted from these data, similarly to what is performed during a single-point calibration. Repeatability can be evaluated by performing the very same pattern of increasing and decreasing concentration on multiple sensors. This protocol is essential to validate sensor performance over time.

This continuous validation can be realized by using two different setups. The first one, more traditionally employed in electrochemistry, is based on sensor immersion in a beaker initially containing only the supporting electrolyte solution continuously stirred to ensure homogeneity. Before starting with the following additions, the sensor needs to be left in the supporting electrolyte solution for a period ranging from 2 to $10 \mathrm{~min}$ to stabilize. This period depends on the geometry of the sensor and the amount of liquid. Each step of increasing concentration is then achieved by adding standard additions of a highly concentrated solution, each decreasing, adding further diluting supporting electrolyte solution after the maximum concentration is reached. The amount of liquid and the velocity of the stirring process should be optimized since these aspects can affect the sensitivity of the resulting calibration curve.

The second setup, which resembles more realistically the real-operation conditions of the sensors, is based on the integration of the sensor itself within a dedicated microfluidic circuit. Essential elements of this circuit—which can be realized with various technologies- 
are: (1) a sample pad or wick used to collect the sample; (2) a thin channel necessary to continuously deliver the sample on top of the electrodes; (3) a waste reservoir needed to discard the already measured samples. The starting point level is usually obtained by providing a continuous flow of supporting electrolyte solution on top of the sensing electrodes to reach a steady-state level. After that, flows with increasing and decreasing concentrations are provided to the electrodes, and their response is measured. Using this second setup, the velocity of the flow is the main variable that can affect the response time and the sensitivity of the measurements. Thus, particular attention in dynamic calibration performed with the sensor integrated into microfluidic circuits is addressed to the optimization of the materials and geometries used to form the wick, channels, and waste reservoir in order to provide a continuous flow [31]. Furthermore, additional tests of the sensors integrated into standardized setups with controlled flows are often performed, in order to find the influence of flow rate on sensor sensitivity [35].

The time stability of both the setups described can be then evaluated by long-term stability tests of the response of the sensor to a fixed concentration and flow rate over a long period, continuously [29,31], or at discrete time points [32].

\subsubsection{Validation Tests with Interfering Analytes}

The second stage required to validate electrochemical sensors included in mobile or wearable devices encompasses the in vitro evaluation of their performances in presence of controlled concentrations of interfering agents in addition to the target analyte. By using this approach, it is possible to estimate the selectivity of the biosensor under near realistic working conditions. This analysis is usually referred to as an "interferent test" or "selectivity evaluation" since it focuses on the evaluation of the selectivity of the designed sensor against the target analyte even in presence of other analytes (e.g., electrolytes, metabolites, or proteins) that are physiologically present in human sweat.

The evaluation of the performance of sensors in non-ideal conditions can be either performed by adding standard solutions with a controlled concentration of interfering analytes [32,33] or by exploiting more complex multi-analyte solutions, also known, in this case, as "artificial sweat" [29]. In the first case, a solution containing a fixed concentration of the target analyte is measured until a steady state is reached. Then, during the same measurement (e.g., potentiometric, amperometric), interferents of known volume and concentration are added. In the final measurement, knowing the timepoint at which the addition of interferents was performed, it is possible to quantify their effect on the steadystate current measured. While performing those tests the change in sensor response (i.e., potential level, current peak amplitude, steady-state current) should be evaluated and quantified-in absolute or percentage terms [33]. For this specific application, the types of interfering agents are usually chosen considering the physiological composition of human sweat and are mainly: uric acid, ascorbic acid, glucose, lactate, and anions or cations other than the target ones.

Artificial sweat and sweat from control patients are some of the most useful fluids used directly as diluting buffer for the target analyte. The influence of interfering agents on the output of the sensor is usually evaluated considering different proportions between the target analyte and the interfering elements, to understand if there is a specific threshold above which they start to interfere. This can be obtained by employing different dilutions of the artificial sweat to change the concentration of interferents in the final solution [45].

\subsection{In Vivo/Clinical Validation}

Once the laboratory validation of the biosensor has been completed, the following step refers to the validation of the overall mobile or wearable PoCT device in non-controlled conditions, during realistic operation. Since, in this phase, it is essential to test the device as a whole stand-alone platform, highly portable, customized electronics, properly interfaced with the biosensor are used. This stage is essential to account for all the contour variables including influences of interferents, movement artifacts, time, humidity, and 
overall reliability of the mobile or wearable customized electronics. Concerning these issues, comprehensive information from the analyzed papers is summarized in Table 4.

For the identified application, the validation with real sweat samples can be distinguished mainly between ex situ analysis, taking into consideration samples previously sampled from human subjects, and in situ analysis, evaluating the wearable device during its real on-body operation.

Both ex situ and in situ sweat analysis can be performed on sweat collected spontaneously as a consequence of the subject performing physical exercises or thanks to a sweat induction through standard iontophoresis. The indoor cycling bike [12] or the treadmill [11] were typically used to control physical activity and the workload. For example, an elevation of the lactate concentration can be obtained by increasing the treadmill speed. Sweat induction through standard iontophoresis is a fairly widespread technique [38], especially for those experiments that are focused not on monitoring sweat during exercise, but on evaluation of particular physio-pathological conditions (e.g., stress or cardiac issues) [32,46]. In other cases, sweat analysis was used as an alternative to invasive blood analysis; for instance, in [38], the ethanol concentration measured in sweat by the proposed biosensors was demonstrated as a non-invasive method for the determination of ethanol concentration in the blood and a valuable alternative to the breathalyzer, especially for preventing measurement alteration by the users. The typical sweat induction is referred to as active iontophoresis (IZASA). Briefly, two recessed stainless-steel electrodes, covered with a gel containing pilocarpine are strapped on the target site of the subject's body and a small electrical current (usually around $1.5 \mathrm{~mA}$ ) is passed through the electrodes for $5 \mathrm{~min}$ by using a battery-powered device. The electrodes are usually then removed and two paths can be followed: the induced sweat is directly collected and analyzed ex situ [33] or the wearable biodevice is positioned onto the same spot and the measurement performed directly in situ [32,38]. According to the characteristics of the biosensor (i.e., disposable or reusable, repeatability, reproducibility, stability, etc.), the device could be tested in continuous single measurement modes [38]. Although the definition of the sample size is fundamental from the clinical perspective, among the considered papers, the number of volunteers-used as a control group-ranged from 1 to 40 [38].

\subsection{Validation against "Gold Standard" Assays}

Proper validation of any biosensor performances cannot be considered complete without a comparison of the results obtained with the outputs from "gold standard" methods, which are well accepted and certified in laboratories. The choice of the specific method depends on the category to which the target analyte belongs (e.g., protein, metabolite, or electrolyte). Those methods are represented by the "gold standard" techniques that are routinely adopted in wet laboratories (e.g., spectrophotometry, atomic force microscopy, optical measurements, chromatography, and standard protein quantification assays) but also by commercially available certified portable devices (e.g., glucometers, lactometers, and breath analyzers).

Regarding $\mathrm{pH}$ electrodes, the most-adopted reference technique is a standard $\mathrm{pH}$ meter comprising a solid electrode in a bulb and that is re-calibrated before any measurement to ensure high accuracy [34,42].

Regarding sweat rate measurement, the commonly adopted methods rely on an optical system (e.g., Macroduct system) that represents a standard sweat collection system used in cystic fibrosis diagnosis. This solution is extremely useful in optical sweat rate measurement since it can be worn on a small region of the body to measure the local sweat content and sweat rate [31].

Moreover, different methods are reported to be useful in validating biosensors addressing electrolyte quantification, such as atomic absorption spectrophotometer (e.g., for $\mathrm{Ca}^{2+}$ ) [42] or ion chromatography (e.g., for $\mathrm{Cl}^{-}$) [29].

Further, the performance of sensors addressing metabolites (e.g., glucose or lactate) is usually validated using commercial strips combined with a 5glucometer/lactometer [32,45]. 
Differently, biosensors addressing alcohol quantification have been reported to be validated following different methods. A first approach relies on the use of a commercial FDA-approved breath analyzer that is able to quantify the analyte in breath [32], whereas a second approach is based on the use of a gas chromatography-based blood analysis of prewarmed, free-flowing, fingertip punctures into heparinized capillary tubes [38]. A third method relies on the measurement of salivary lactate using a commercial immunoassay kit [22].

\section{Electronics Design Considerations}

Regarding the different examples of conditioning and transmission electronics proposed in the analyzed papers, despite the evident use of different designs and specific components, a common scheme could be recognized; this overall approach allowed us to track useful indications for researchers of the field. It is worth further noting, that the electronic components play a fundamental role in the overall reliability of any complete PoCT device. All the information concerning electronics design and choices acquired from analyzing the papers is summarized in Table 5 and visually summarized in Figure 2.

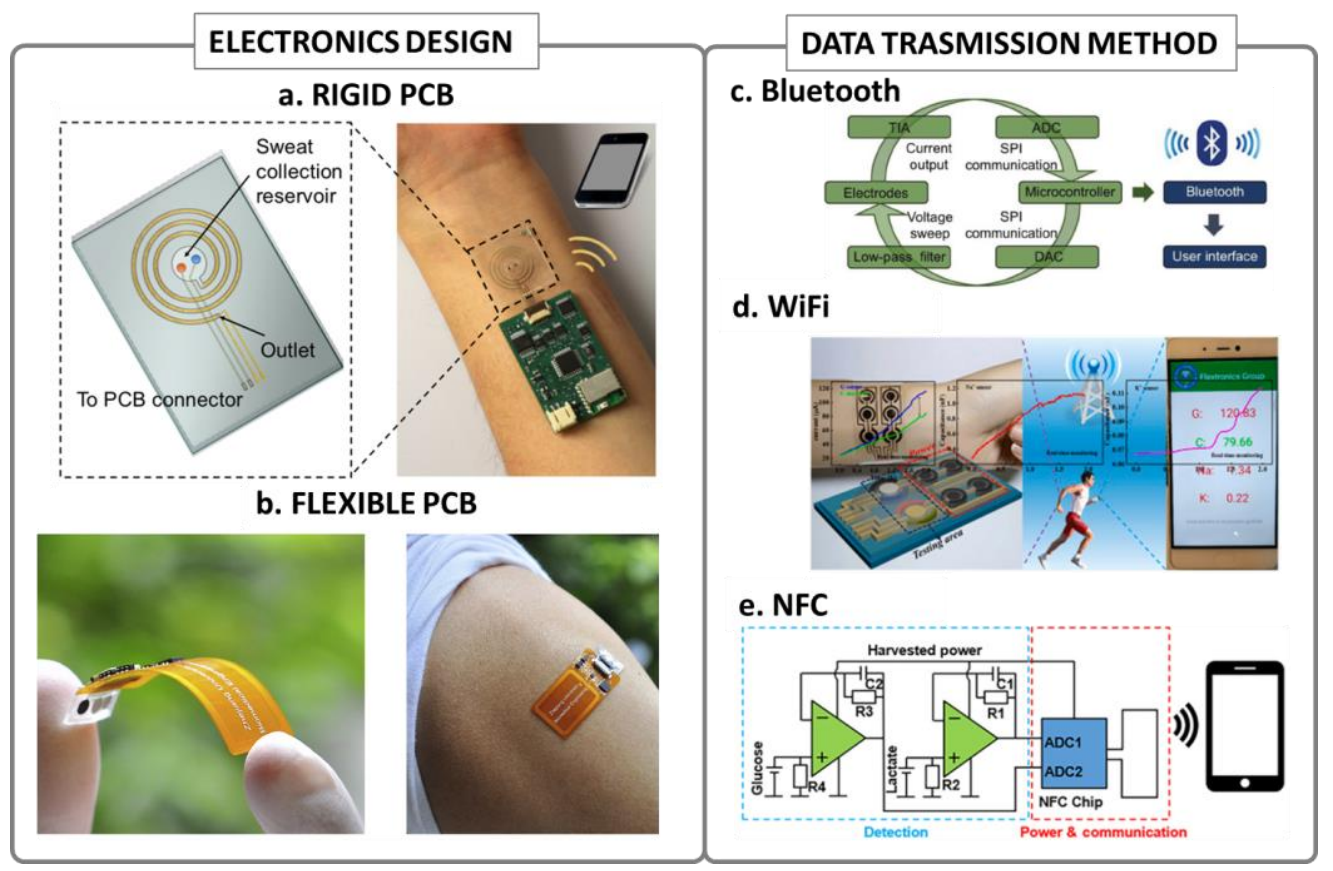

Figure 2. Wearable electronics design and connectivity: (a) example of a wearable device with rigid PCB electronics, reproduced with permission from [31], copyright 2018, American Chemical Society; (b) example of a flexible polyimide circuit integrated in a wearable sensing device, reproduced with permission from [29], copyright 2020 Elsevier; (c) typical block scheme of a Bluetooth-based wearable device, reproduced with permission from [33], copyright 2018 WILEY-VCH Verlag GmbH \& Co. KGaA, Weinheim; (d) typical block scheme of a WiFi-based wearable device, reproduced with permission from [47], copyright 2019 Elsevier; (e) typical example of an NFC-based wearable device block scheme, reproduced from [45], open access.

First of all, essential considerations for the design of suitable electronics include, from one side, the requirements related to portability, ease, and duration of use and, from the other side, the requirements related to accuracy, resolution, and precision.

Regarding the first set of requirements, one of the most relevant aspects is the material of the substrate on which the electronic components are soldered, as well as its enclosure and integration with the sensor's microfluidic part. Despite most of the examples reported still proposing standard miniaturized circuits realized on rigid printed circuit boards (PCB) $[31,33]$, an interesting example of evolution toward flexible electronics can 
be observed. The first approach presented in [35] proposed ensuring flexibility of the electronic part by enclosing a rigid PCB in a properly designed flexible material, to avoid displacement during exercise. The second approach presented in $[29,32]$ reported the use of flexible materials, such as polydimethylsiloxane [45] and polyimide [29,48] as useful substrates on which electronic components can be directly fixed thanks to suitable conductive epoxy glues.

Another relevant aspect to deal with is the battery life and overall power consumption. To enable stand-alone wireless functioning of the mobile or wearable PoCT devices, rechargeable lithium-ion batteries with a nominal voltage of $3.0 \mathrm{~V}[32,48]$ or $3.7 \mathrm{~V}[31,33]$ are usually adopted [33], which ensures a use duration of a few hours [32,35,49]. Furthermore, the conditioning system is typically a single-supply system, and the electronic components are selected in order to reduce the power consumption and thus extend the overall battery life. An interesting approach for the power supply is the design of battery-free biosensors, where power is harvested in the proximity of NFC-enabled smartphones then modulated to a stable voltage output for MCU and AFEs ( $2.76 \mathrm{~V})$ [29].

The first stage of the electronics interfacing with the connections to the electrodes of the biosensor depends upon the category of electrochemical biosensors, i.e., amperometric, potentiometric, or impedimetric. In amperometric sensors, a three-electrodes layout is usually adopted, with working (WE), reference (RE), and auxiliary (AE) electrodes. The transducer circuit is composed of two elements: a control circuit, to keep the voltage potential of the electrochemical cell stable, and a current-to-voltage (I/V) converter, based on a transimpedance amplifier, to measure very low currents reducing the effect of changes in the output impedance [33]. In potentiometric and impedimetric sensors a two-electrode layout is usually adopted, with only WE and RE [31]. For potentiometric measurements, the conditioning circuit is composed of a control circuit and an instrument amplifier, that ensures amplification of the input voltage between the electrodes WE and RE, by guaranteeing, at the same time, a very high input impendence. A combination of a variable frequency generator and a frequency analyzer is generally used for impedimetric measurements [35]. This allows stimulation of the electrochemical cell at different frequencies, and the analysis of the resulting alternate current to compute the cell impedance. Operational amplifiers are used also for active filter stages to filter the signal and remove the noise as well as for gain stages. For example, in [20], the signal conditioning circuit was designed to amplify the current measured by the biosensor between 1000 and 2831 times to obtain a measurable voltage output. Rail-to-rail inputs and outputs, output stability over time, and high gains at lower supply voltages are fundamental features for the selection of the operational'amplifiers.

The remaining blocks of the conditioning electronics are quite common among all the electronics proposed, and, in general, include:

- Customized high impedance analog front ends to process voltage signals of the two or three electrodes to output stable voltages;

- Built-in analog to digital converters (ADCs) to convert the analog signal into digital signals;

- A micro-controller unit (MCU), usually programmable, that manages all the operations on the board;

- A display [20];

- A transceiver (typically a Bluetooth module) to wirelessly transmit the data provided by the MCU to a user interface for displaying the measurements on a laptop or mobile. Although integrated Bluetooth low energy (BLE) represents the most frequently employed method for wireless transmission from the wearable device to laptops [22,31], or smartphones [31], interesting examples can be found adopting also an NFC-based transmission $[29,34]$. This recent method can improve miniaturization since the power supply can be harvested from mobile phones via NFC, thus resolving the need for battery integration in the wearable device. As opposed to BLE-based PoCT, the NFC- 
based solutions need a short distance between the PoCT and the reader and allow single-point measurements.

- A DC-DC converter (or low-dropout voltage regulator, etc.) to realize regulated and stable voltage from one single power supply and suitable for all the electronic sections - the analog front end and the digital components and the transceiver-which can need different voltage supplies [33].

If the platform consists of multiple sensors, multiplexes or high-voltage switches are required to measure multiple sensors within the same measurement chain $[32,34,44]$. In this way, the size and power consumption of the platform do not depend on the number of the sensors and can be kept to a minimum.

\section{Discussion}

The analysis of the works included in this review allowed us to identify not only recurring trends and useful guidelines but also limitations and gaps in the validation procedures more commonly adopted to validate complete PoCT devices, in a stand-alone configuration.

Although similar protocols and validation phases can be recognized, the papers analyzed often show several missing steps and stages, thus preventing recognition of a shared uniform standardized workflow that can-and should-be used for characterization.

The effort in trying to standardize methods for characterizing chemical and biological sensors can be highlighted in the literature produced during the last two decades [50,51]. However, emerging from this review is a lack of procedure standardization and the absence of clear scientific references able to explain why the validation protocol was organized in that specific way. This represents the main gap that exists between the validation of biochemical sensors, and the widespread physical sensors (e.g., accelerometers, pressure sensors), making them less robust and not yet ready for the commercialization stage. Despite this delay, the performed analysis shows an improvement in the procedures in terms of standardization and the number of metrological parameters reported in the last 5 years. Increased attention to, and a more accurate description of protocols used to characterize the biosensors, at least for the in vitro phase, can be seen [45].

An element of weakness that could be noticed even in papers with a relatively complete and standardized characterization procedure is the lack of indication of the number of samples or subjects evaluated and how average measures and standard deviation information were calculated; indeed, this represents a limitation since only the knowledge of sample dimension can discriminate between a proof-of-concept and a properly working biosensor that can proceed further to clinical trial testing or commercialization.

Another crucial point not always considered in the analyzed papers is represented by a proper comparison of the output of the wearable PoCT device under assessment with respect to commercially available certified systems. This comparison should include two different stages. The first unavoidable step is the comparison of the performance of customized electronics with results obtained using benchtop or portable commercial potentiostats while performing the same electrochemical measurement (e.g., amperometric, potentiometric, or impedimetric); this represents a preliminary fundamental step of the validation procedure, which is essential to ensure the reliability of any customized electronics integrated into mobile or wearable platforms. Often this comparison is missing within the same publication $[33,38]$, whereas in a few papers authors declare only that the customized electronics provides similar measurements to the ones provided by the benchtop equipment [47]. In further studies, the performances of the mobile or wearable electronics during in vivo measurements are validated by comparing the results of analyte quantification with results from an ex situ analysis performed by benchtop instrumentation $[43,52]$. Once this reliability is guaranteed, it is possible to proceed with a second comparison: the validation of the outputs with those ones obtained from "gold standard" approaches, routinely adopted in wet labs. This validation is essential to ensure that the transducing principle of the biosensors included in the wearable devices is coherent with "gold standard" techniques, both in terms of absolute results and, especially, in terms of 
reproducibility and stability over time. Regarding this type of comparison, even when present, it often lacks proper quantitative parameters that could help to better characterize it. Accuracy and recovery value thus are often missing from the parameters indicated in papers. Indeed, as reported quantitatively $[29,33,34,43]$ or only qualitatively $[42,45]$ by some of the papers analyzed, these parameters represent a significant figure of merit to verify the reliability of the proposed novel methods in comparison with existing ones.

Finally, information about the comfort and the ease of use represent crucial aspects in the development of wearable solutions; however, this point was not always provided by the authors [38], even when the design optimization was studied extensively [35]. In more recent publications, movies of the real-time ex situ analyses operated by the proposed PoCT are provided [47] or extensive and detailed information about the practical use of the developed customized application are reported [29,33,43,48]. Regarding comfort, most of the analyzed works simply state that thanks to soft encapsulating materials (e.g., PDMS) the device can be comfortably worn by subjects [43,52]. Interesting analysis was performed in [29], where a specific combination of PDMS and silver nanowires was tested to achieve high stretchability of the electrodes with an all-printing technique, to accommodate to skin deformations, without compromising the distinct conductivity change of the wires. Another interesting analysis to ensure proper compatibility between comfort and performances was observed in [52] where extensive mechanical characterization of the device was reported, simulating stress due to continuous use.

In general, the focus of the analyzed papers is on the sensor design and its performance, while the measurement system is lightly described, or its description is only included in the supplementary material. In some cases, the power source and its nominal value are not reported in the text, such as in $[38,44,47]$, as well as the power consumption [31,33]. The main thing to remember is that the circuit contributes significantly to the final results (for example on the accuracy and LOD). For example, the operational amplifiers and the passive components can increase the electrical noise when the input and output of the impedance converter are not properly biased because the metal electrodes can be polarized and this alters the measurements [31]. A proper filtering circuit is needed for a reliable measurement. An RC low-pass filter is often chosen [48,49], while active filters guarantee the best performance [31,33]. The sensor-electronics interface should also be properly designed. For example in [35], the electronics are rigidified in order to reduce the voltage offset due to the pressure induced by the patch on the case.

The nonuniformity in metrological parameters represents another key element that can be highlighted from the present analysis. Although at least one metric of sensitivity, slope, or LOD is given, they are often presented in non-standardized forms and often reported only graphically and/or left to be deduced from calibration curves. A similar discussion can be had on linearity, often reported with non-standardized indicators, or just stated qualitatively, and for repeatability and reproducibility, often confused or mistakenly overlapped. Further, selectivity and stability are often commented only in a qualitative way, without proper quantitative indicators, as reported in [35,43] but not provided in [31]. However, defining those parameters in quantitative terms represents a crucial point in the comparison among repetitive measurements even when considering replicated setups. Focusing on stability, accurate computation of both operational and storage stability is fundamental to improve sensor design and to better understand their behavior, as highlighted in [34,45]. Interesting examples can be found in [52], where results from the evaluation of stability are exploited to define a proper protocol for periodic calibrations; in [49] this information is used to improve the process for the fabrication of the microfluidic system in which biosensors are integrated; and finally, in [53], the authors discussed how stability results can be used to eventually design proper algorithms for compensating biosensor performances degradation during both operation and their shelf-life. 
Table 1. Summary of specific analytes and transducing methods.

\begin{tabular}{|c|c|c|c|c|}
\hline REF & Analyte & Mediator & Selective Layer & Transducing Principle \\
\hline Liang 2021 [49] & $\mathrm{K}^{+}$ & none & ion-selective membrane for $\mathrm{K}^{+}$ & potentiometric \\
\hline Zhang 2021 [43] & $\mathrm{K}^{+}$ & none & ion-selective membrane for $\mathrm{K}^{+}$ & potentiometric \\
\hline Vinoth 2021 [42] & Lactate, $\mathrm{Na}^{+}, \mathrm{K}^{+}$, and $\mathrm{pH}$ & Prussian Blue & $\begin{array}{l}\text { lactate oxidase enzyme } \\
\text { target-specific ionophores }\end{array}$ & $\begin{array}{l}\text { amperometric } \\
\text { potentiometric }\end{array}$ \\
\hline Wenya 2019 [44] & $\begin{array}{l}\text { glucose, lactate, ascorbic acid (AA), uric } \\
\text { acid (AU), } \mathrm{Na}^{+} \text {, and } \mathrm{K}^{+}\end{array}$ & $\begin{array}{l}\text { Pt nanospheres } \\
\text { for glucose and lactate; EDOT: PSS } \\
\text { for } \mathrm{Na}^{+} \text {and } \mathrm{K}^{+} \text {; none for AA and AU }\end{array}$ & $\begin{array}{l}\text { enzymes for glucose and lactate; } \\
\text { ion-selective membranes respectively for } \mathrm{K}^{+} \\
\text {and } \mathrm{Na}^{+} \text {; selectivity ensured by representative } \\
\text { oxidation peaks for AA and } \mathrm{AU} ;\end{array}$ & $\begin{array}{l}\text { amperometric (glucose, lactate), } \\
\text { potentiometric }\left(\mathrm{K}^{+} \text {and } \mathrm{Na}^{+}\right) \\
\text {voltammetric }(\mathrm{AA} \text { and } \mathrm{AU})\end{array}$ \\
\hline Zhang 2019 [34] & $\mathrm{pH}, \mathrm{Na}^{+}, \mathrm{K}^{+}$, and $\mathrm{Ca}^{2+}$ & none & $\begin{array}{c}\mathrm{Al}_{2} \mathrm{O}_{3} \text { sensing layer for } \mathrm{pH} \\
\text { ion-selective membranes respectively for } \mathrm{K}^{+} \text {, } \\
\mathrm{Ca}^{2+} \text { and } \mathrm{Na}^{+} ;\end{array}$ & $\begin{array}{c}\text { amperometric } \\
\text { ion-sensitive field effect transistors } \\
\text { (ISFETs)) }\end{array}$ \\
\hline Lu 2019 [47] & glucose, $\mathrm{Na}^{+}, \mathrm{K}^{+}$ & none & $\begin{array}{c}\text { chitosan } / \mathrm{NiCo}_{2} \mathrm{O}_{4} \text { for glucose; } \\
\text { ion-selective membranes respectively for } \mathrm{K}^{+}, \\
\text {and } \mathrm{Na}^{+} ;\end{array}$ & $\begin{array}{l}\text { amperometric } \\
\text { capacitance sensor }\end{array}$ \\
\hline Sempionatto 2019 [48] & $\mathrm{Na}^{+}, \mathrm{K}^{+}$ & none & $\begin{array}{c}\text { ion-selective membranes respectively for } \mathrm{K}^{+} \\
\text {and } \mathrm{Na}^{+}\end{array}$ & potentiometric \\
\hline Bandodkar 2019 [45] & sweat rate, $\mathrm{pH}$, lactate, glucose, and $\mathrm{Cl}^{-}$ & Tetrathiafulvalene & $\begin{array}{c}\mathrm{pH} \text {-sensitive die and silver } \\
\text { chloranilate; lactate oxidase trapped in CNT } \\
\text { paper; glucose oxidase in Nafion; }\end{array}$ & $\begin{array}{l}\text { colorimetric (rate, } \mathrm{pH}, \mathrm{Cl}^{-} \text {) } \\
\text { biofuel cell ( } \mathrm{Lac} \text { and } \mathrm{Glu})\end{array}$ \\
\hline Xu 2019 [29] & calcium, chloride & none & $\begin{array}{l}\text { Ion-solvent polymeric membrane selective for } \\
\qquad \mathrm{Ca}^{2+} \text {; } \\
\text { electrodes of } \mathrm{Ag} / \mathrm{AgCl} \text { chlorinated in } 3 \mathrm{M} \mathrm{KCl} \\
\text { solution for } \mathrm{Cl}^{-} .\end{array}$ & potentiometric \\
\hline Tai 2018 [33] & caffeine & none & $\begin{array}{l}\text { selectivity ensured by representative oxidation } \\
\text { peaks for caffeine }\end{array}$ & voltammetric \\
\hline Nyein 2018 [31] & $\mathrm{H}^{+}, \mathrm{Na}^{+}, \mathrm{K}^{+}, \mathrm{Cl}^{-}$ & none & $\begin{array}{c}\text { ionophore cocktails coated } \\
\text { with selectivity respectively for } \mathrm{H}^{+}, \mathrm{Na}^{+}, \mathrm{K}^{+} \\
\qquad \mathrm{Cl}^{-}\end{array}$ & potentiometric \\
\hline Alizadeh 2018 [35] & $\mathrm{Na}^{+}$and $\mathrm{K}^{+}$ & none & $\begin{array}{l}\text { ion solvent-polymeric membrane selective for } \\
\qquad \mathrm{Na}^{+} \text {and } \mathrm{K}^{+}\end{array}$ & potentiometric \\
\hline Kim 2018 [32] & glucose and alcohol & Prussian blue & enzymes & amperometric \\
\hline Gao 2016 [52] & glucose, lactate, sodium, potassium & Prussian blue & $\begin{array}{l}\text { enzymes for glucose and lactate } \\
\text { ion-selective membranes }\end{array}$ & $\begin{array}{l}\text { amperometric, } \\
\text { potentiometric }\end{array}$ \\
\hline Gamella 2014 [38] & alcohol & ferrocene & alcohol oxidase/horseradish peroxidase & amperometric \\
\hline
\end{tabular}


Table 2. Summary of biosensors specific features.

\begin{tabular}{|c|c|c|c|c|c|}
\hline REF & Sensor Geometry & Electrodes Material & Sensor Substrate Material & Fabrication Technology & Microfluidic Integration \\
\hline Liang 2021 [49] & $\begin{array}{l}\text { two-electrode layout } \\
\text { Circular ( } 2 \text { mm diameter) }\end{array}$ & $\begin{array}{l}\text { WE: carbon + PEDOT:PSS } \\
\text { RE: silver/silver chloride } \\
\text { blue insulator layer }\end{array}$ & flexible PET & screen-printing & paper-based microfluidic \\
\hline Zhang 2021 [43] & $\begin{array}{l}\text { two-electrode layout } \\
\text { Circular }\end{array}$ & $\begin{array}{l}\text { WE: MWCNTs and MXene-Ti3C2TX } \\
\text { RE: silver/silver chloride }\end{array}$ & flexible PET & screen-printing & PDMS microfluidics \\
\hline Vinoth 2021 [42] & $\begin{array}{l}\text { two-electrode layout } \\
\text { rectangular, parallel electrodes }\end{array}$ & $\begin{array}{l}\text { WE: carbon } \\
\text { RE: silver } \\
\text { Insulator layer }\end{array}$ & flexible polyimide sheet & screen-printing & 3D printed microfluidic \\
\hline Wenya 2019 [44] & $\begin{array}{c}\text { three-electrode layout for } \\
\text { amperometric } \\
\text { two-electrode layout for } \\
\text { potentiometric, circular ( } 3 \mathrm{~mm} \\
\text { diameter) }\end{array}$ & $\begin{array}{l}\text { WE and CE: SilkNCT } \\
\text { RE: } \mathrm{Ag} / \mathrm{AgCl}\end{array}$ & $\begin{array}{l}\text { nickel conductive tape and } \\
\text { flexible PET }\end{array}$ & sewed & silk-based porous structure \\
\hline Zhang 2019 [34] & $\begin{array}{l}\text { CMOS sensor chip containing five } \\
\text { groups of 3D-EMG-ISFET sensors } \\
\text { linearly distributed }\end{array}$ & $\begin{array}{c}\text { electrodes: } \mathrm{Au} \\
\text { passivation layers: } \mathrm{Si}_{3} \mathrm{~N}_{4} \text { and } \mathrm{SiO}_{2} \\
\text { WE for } \mathrm{pH}: \mathrm{Al}_{2} \mathrm{O}_{3} \\
\text { quasi reference electrode (QRE): } \\
\mathrm{Ag} / \mathrm{AgCl}\end{array}$ & silicon layer & photolithography & cotton-based microfluidic \\
\hline Lu 2019 [47] & $\begin{array}{c}\text { two-electrode layout: } \\
\text { concentric circular electrode arrays } \\
\text { can be divided into power units } \\
\text { (micro-supercapacitors, red dots part) } \\
\text { and sensor arrays (dark dots part), } \\
\text { respectively }\end{array}$ & $\begin{array}{c}\mathrm{Cr}(30 \mathrm{~nm}) / \mathrm{Au}(50 \mathrm{~nm}) \text { electrodes } \\
\mathrm{Al}_{2} \mathrm{O}_{3} \text { insulation layer. }\end{array}$ & PET & $\begin{array}{l}\text { photolithography; } \\
\text { Atomic Layer Deposition; }\end{array}$ & none \\
\hline Sempionatto 2019 [48] & 2 electrode layout & $\begin{array}{l}\text { WE: Carbon } \\
\text { RE: } \mathrm{Ag} / \mathrm{AgCl}\end{array}$ & PDMS & $\begin{array}{c}\text { screen Printing; } \\
\text { photolitography; } \\
\text { electron } \\
\text { beam evaporation; }\end{array}$ & $\begin{array}{c}\text { traditional } \\
\text { PDMS/PMMA-based } \\
\text { microfluidic pattern realized } \\
\text { via photolitography }\end{array}$ \\
\hline Bandodkar 2019 [45] & $\begin{array}{l}\text { two-electrode layout, } \\
\text { anode and cathode }\end{array}$ & $\begin{array}{c}\text { current collector: gold } \\
\text { LaC anode: carbon nanotube (CNT) } \\
\text { paper+ chitosan+ polyvinyl chloride } \\
\text { LaCcathode: platinum black + Nafion } \\
\text { Glu anode: carbon nanotube (CNT) } \\
\text { paper } \\
\text { Glu cathode: } \\
\text { platinized carbon + Nafion }\end{array}$ & Polyimide & $\begin{array}{l}\text { photolithography } \\
\text { drop casting; }\end{array}$ & $\begin{array}{l}\text { paper-based microfluidics and } \\
\text { microfluidic pattern via } \\
\text { PDMS-based photolithography }\end{array}$ \\
\hline
\end{tabular}


Table 2. Cont.

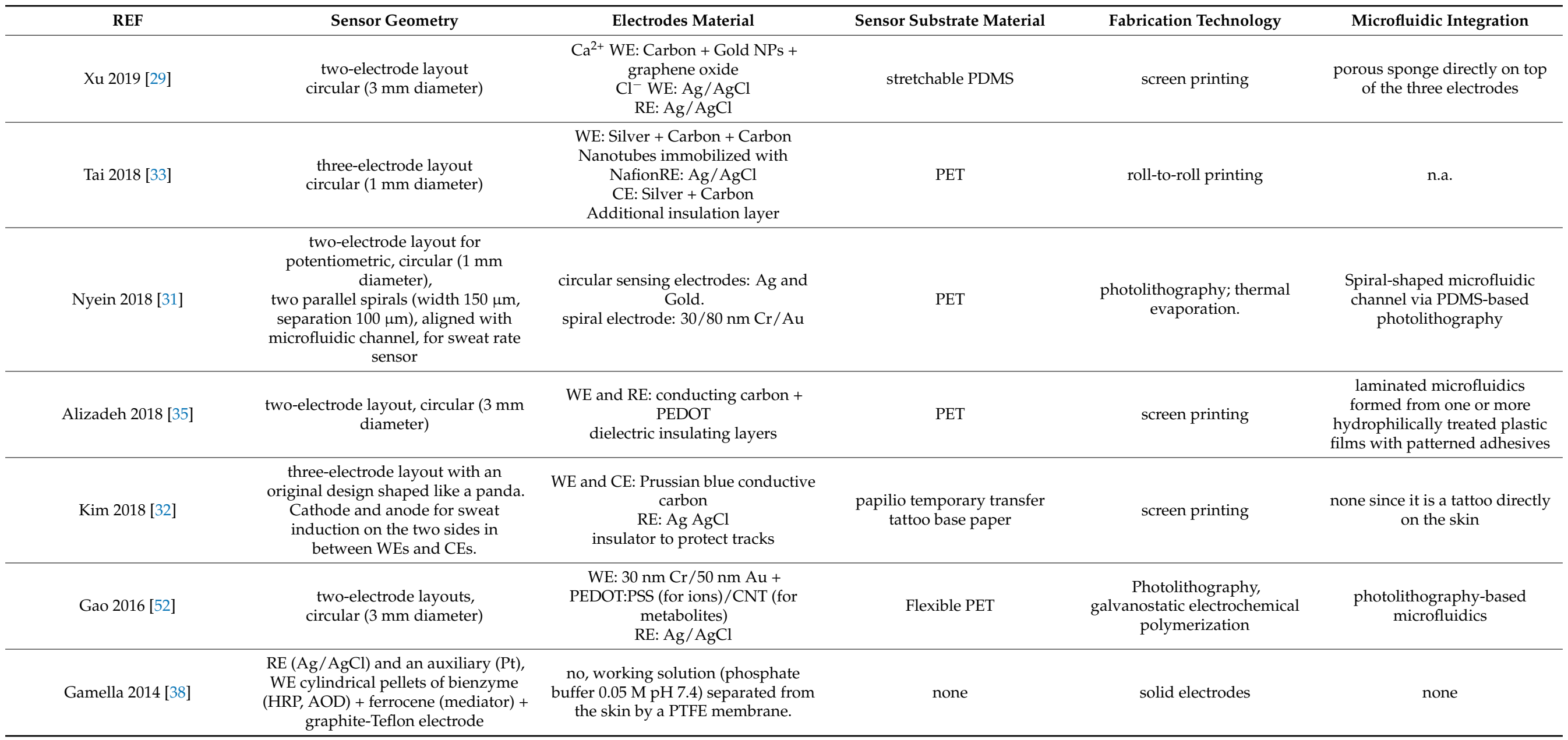


Table 3. Summary of in vitro characterization protocols.

\begin{tabular}{|c|c|c|c|c|c|}
\hline REF & Number of Sensors & $\begin{array}{l}\text { In Vitro Diluting } \\
\text { Solution Used }\end{array}$ & Calibration Protocol & Selectivity Test & Stability Test \\
\hline Liang 2021 [49] & 5 & Deionized water & $\begin{array}{c}\text { Continuous calibration: each sensor subjected } \\
\text { to increasing concentration of } \mathrm{K}^{+} \\
\text {(non-homogeneous steps from } 1 \mathrm{mM} \text { to } 32 \\
\mathrm{mM} \text { ). Response time computed from the } \\
\text { curve obtained. } \\
\text { All measurements performed using an } \\
\text { electrochemical workstation. }\end{array}$ & $\begin{array}{l}\text { Change in sensor response measured when } \\
\text { selected interfering analytes }\left(\mathrm{Mg}^{2+},\right. \\
\mathrm{Na}^{+}, \mathrm{Ca}^{2+}, \mathrm{HCO}_{3}{ }^{-}, \mathrm{NO}_{3}{ }^{-}, \mathrm{SO}_{3}{ }^{2-}, \text { lactate, } \\
\text { Uric Acid, and Glucose) were added in the } \\
\text { solution. }\end{array}$ & $\begin{array}{l}\text { Long-term stability of the sensor } \\
\text { was evaluated over a period of } \\
\text { eight days }\end{array}$ \\
\hline Zhang 2021 [43] & 5 & PBS & $\begin{array}{c}\text { Continuous calibration: each sensor subjected } \\
\text { to increasing concentration of } \mathrm{K}^{+} \\
\text {(non-homogeneous steps from } 1 \mathrm{mM} \text { to } 32 \\
\mathrm{mM} \text { ). } \\
\text { The repeatability analysis of the sensor } \\
\text { evaluated systematically by observing the } \\
\text { potential response of } \\
\text { two sensors on ten separate occasions. }\end{array}$ & $\begin{array}{l}\text { The selectivity experiment of } \\
\text { the sensor carried out by the potential } \\
\text { response method with successive addition of } \\
1 \mathrm{mM}\left[\mathrm{K}^{+}\right] \text {(two-fold), followed by } \\
\text { electroactive interfering species of } 20-\mu \mathrm{M} \\
\mathrm{Zn}^{2+}, 4 \mathrm{mM} \mathrm{Na}^{+} \text {, and } 4 \mathrm{mM} \mathrm{Ca}{ }^{2+} ; \\
\text { and finally; } 8 \mathrm{mM}, 16 \mathrm{mM} \text {, and } 32 \mathrm{mM}^{+}\left[\mathrm{K}^{+}\right]\end{array}$ & n.a. \\
\hline Vinoth 2021 [42] & 6 & PBS, distilled water & $\begin{array}{l}\text { Combined single point and continuous } \\
\text { calibration with increasing concentration } \\
\text { steps for lactate sensors. Only continuous } \\
\text { calibration with both increasing and } \\
\text { decreasing concentration steps for } \mathrm{pH}, \mathrm{Na} \\
\text { and K sensors. }\end{array}$ & $\begin{array}{c}\text { For lactate single chronoamperograms were } \\
\text { recorded with } 5 \mathrm{mM} \text { lactate in the absence } \\
\text { and presence of possible interfering species } \\
\left(\mathrm{Na}^{+}, \mathrm{K}^{+}, \mathrm{UA}, \mathrm{AA}, \mathrm{Glucose}\right) ; \\
\text { For ions change in sensor response was } \\
\text { measured during a continuous } \\
\text { choroamperometry when selected interfering } \\
\quad \text { analytes are added } \\
\text { to the probing solution }\left(\mathrm{NH}_{4}, \mathrm{Ca}^{+}, \mathrm{Mg}^{+}\right)\end{array}$ & $\begin{array}{l}\text { Stability evaluated with repeated } \\
\text { measurements over a period of } \\
10 \text { month }\end{array}$ \\
\hline Wenya 2019 [44] & 5 & $0.1 \mathrm{M}$ PBS (pH 7.0) & $\begin{array}{l}\text { Continuous calibration: each sensor subjected } \\
\text { to increasing concentrations (low to high) of } \\
\text { each target analyte. }\end{array}$ & $\begin{array}{c}\text { Change in sensor response measured when } \\
\text { selected interfering analytes are added } \\
\text { to the probing solution }\end{array}$ & $\begin{array}{l}\text { Measurement performed each } \\
\text { week over a period of } 4 \text { weeks }\end{array}$ \\
\hline Zhang 2019 [34] & n.a. & $\begin{array}{l}\text { PBS and Artificial sweat } \\
\text { containing } 10 \mathrm{mM} \mathrm{KCl}\end{array}$ & $\begin{array}{l}\text { Continuous calibration: each sensor subjected } \\
\text { to increasing and decreasing } \\
\text { concentration/pH step changes }(10 \mathrm{mM}, 20 \\
\mathrm{mM} \text { and } 100 \mathrm{mM} \text { for }\left[\mathrm{Na}^{+}\right] \text {and } 4,5,6,7,8 \text { for } \\
\mathrm{pH}) .\end{array}$ & $\begin{array}{l}\text { Change in sensor response measured } \\
\text { bringing the tested solution to different } \\
\text { pH and adding interfering ions }\end{array}$ & $\begin{array}{l}\text { Measurement during time with a } \\
\text { dynamic response of the sensor }\end{array}$ \\
\hline Lu 2019 [47] & n.a. & Not specified & $\begin{array}{l}\text { Continuous calibration: increasing } \\
\text { concentrations were dropped subsequently on } \\
\text { the sensor. Glucose from } 10 \text { to } 200 \mu \mathrm{m} /\left[\mathrm{Na}^{+}\right] \\
\text {from } 10 \text { to } 160 \mathrm{mM} /\left[\mathrm{K}^{+}\right] \text {from } 1 \text { to } 16 \mathrm{mM} \text {. }\end{array}$ & $\begin{array}{l}\text { Change in sensor response measured when } \\
\text { lactate solution is added } \\
\text { as interfering molecule. }\end{array}$ & $\begin{array}{l}\text { Variation of capacitance stability } \\
\text { of MSCs with 20,000 cycles. }\end{array}$ \\
\hline
\end{tabular}


Table 3. Cont.

\begin{tabular}{|c|c|c|c|c|c|}
\hline REF & Number of Sensors & $\begin{array}{l}\text { In Vitro Diluting } \\
\text { Solution Used }\end{array}$ & Calibration Protocol & Selectivity Test & Stability Test \\
\hline Sempionatto 2019 [48] & n.a. & $\begin{array}{l}\text { Deionized water or artificial } \\
\text { sweat (composed of urea, lactic } \\
\text { acid, } \mathrm{NH}_{4}^{+}, \mathrm{Ca}^{2+}, \mathrm{Mg}^{2+} \text {,uric } \\
\text { acid, glucose, } \mathrm{Na}^{+} \text {and } \mathrm{K}^{+} \text {) }\end{array}$ & $\begin{array}{l}\text { Continuous calibration: injected on the sensor } \\
\text { through a six-port valve varying } \\
\text { concentrations of sodium }(0.1 \text { to } 200 \mathrm{mM}) \text { and } \\
\text { potassium ( } 0.1-100 \mathrm{mM}) \text { with } 10 \text {-fold } \\
\text { increments. }\end{array}$ & not performed & $\begin{array}{l}\text { Visual examination of the } \\
\text { resiliency to mechanical strain: i) } \\
\text { skin mounted device and the } \\
\text { device under different strain } \\
\text { tests: ii)t wisting, iii) bending and } \\
\text { iv) stretching. Also, EMF stability } \\
\text { of the sensor over several days } \\
\text { (tested several days during a } \\
\text { week period) for static system } \\
\text { using } 10 \mathrm{mM} \text { ion concentration in } \\
\text { water }\end{array}$ \\
\hline Bandodkar 2019 [45] & 3 & PBS, artificial sweat & $\begin{array}{l}\text { Continuous calibration: sensor suspended in } \\
\text { a beaker containing buffer on a hot plate with } \\
\text { controlled temperature starting from a } \\
\text { no-analyte baseline and then adding } \\
\text { increasing concentrations of glucose/lactate. }\end{array}$ & $\begin{array}{l}\text { Change in sensor response measured on } \\
\text { addition of common interferents (ascorbic } \\
\text { acid, uric acid, and glucose) in physiologically } \\
\text { relevant concentrations. }\end{array}$ & $\begin{array}{l}\text { Sensors exposed to } 10 \mathrm{mM} \\
\text { lactate } / 150 \mathrm{uM} \text { glucose solution } \\
\text { for } 20 \mathrm{~min} .\end{array}$ \\
\hline Xu 2019 [29] & 5 & $\begin{array}{l}\text { Deionized water, } \\
\text { Artificial serum, Artificial } \\
\text { urine, Artificial tear, human } \\
\text { sweat samples }\end{array}$ & $\begin{array}{l}\text { Continuous calibration: during a single long } \\
\text { potentiometric measurement, sensors } \\
\text { subjected to concentration changes of target } \\
\text { analyte from low to high and then from high } \\
\text { to low. Linearity range and LOD were then } \\
\text { calculated from steady-state value of each } \\
\text { outstepped step. }\end{array}$ & $\begin{array}{l}\text { Change in sensor response measured when } \\
\text { potential positive and negative interfering } \\
\text { ions are added to the solution tested, in } \\
\text { details: } \\
\text { for } \mathrm{Cl}^{-} \text {sensor using } \mathrm{HCO}_{3}^{-}, \mathrm{CO}_{3}^{-} \\
\quad \mathrm{OH}^{-} \text {and } \mathrm{NO}_{3}^{-} \\
\text {for } \mathrm{Ca}^{2+} \text { sensor using } \mathrm{Na}^{+}, \mathrm{K}^{+}, \mathrm{H}^{+}, \mathrm{NH}_{4}^{+}\end{array}$ & $72 \mathrm{~h}$ potentiometric recording \\
\hline Tai 2018 [33] & n.a. & $\begin{array}{l}\text { Acetate buffer solutions; } \\
\text { human sweat samples }\end{array}$ & $\begin{array}{l}\text { Single point calibration using standard } \\
\text { solutions: caffeine solutions with different } \\
\text { concentrations used on different sensors for } \\
\text { DPV measurements performed with a } \\
\text { commercial potentiometer. } \\
\text { Single point calibration using sweat-based } \\
\text { solutions: caffeine added to sweat samples in } \\
\text { different concentrations. To improve the } \\
\text { sensitivity, accumulation of caffeine } \\
\text { molecules at negative potential. Commercial } \\
\text { potentiostat used for all the measurements. }\end{array}$ & $\begin{array}{l}\text { Change in sensor response measured when } \\
\text { selected analytes (urea, glucose, lactic acid, } \\
\text { ascorbic acid, pilocarpine) were added in } \\
\text { physiologically relevant concentrations to } 40 \\
\times 10^{-6} \mathrm{~m} \text { of caffeine in the acetate buffer } \\
\text { solutions. }\end{array}$ & n.a. \\
\hline
\end{tabular}


Table 3. Cont.

\begin{tabular}{|c|c|c|c|c|c|}
\hline REF & Number of Sensors & $\begin{array}{l}\text { In Vitro Diluting } \\
\text { Solution Used }\end{array}$ & Calibration Protocol & Selectivity Test & Stability Test \\
\hline Nyein 2018 [31] & n.a. & Deionized water & $\begin{array}{l}\text { Combined single point and continuous } \\
\text { calibration of } \mathrm{Na}^{+} \text {sensor and flow rate sensor: } \\
\text { (1) fixing the flow rate, sensing electrodes } \\
\text { exposed to three different } \mathrm{Na}^{+} \text {concentrations. } \\
\text { (2) fixing the } \mathrm{Na}^{+} \text {concentration, spiral } \\
\text { electrode exposed to three different flow rate } \\
\text { values. } \\
\text { (3) continuous monitoring of the } \\
\text { measurement during time to follow how both } \\
\text { sensors respond to step variation in } \mathrm{Na}^{+} \text {or } \\
\text { flow rate }\end{array}$ & Not performed & $\begin{array}{l}\text { Measurement for } 350 \mathrm{~s} \text { for } \mathrm{Na}^{+} \\
\text {sensor and for } 1000 \mathrm{~s} \text { for flow } \\
\text { rate sensor }\end{array}$ \\
\hline Alizadeh 2018 [35] & 3 & Deionized water & $\begin{array}{c}\text { Single point calibration with different salt } \\
\text { concentrations directly on top of electrodes. } \\
\text { Continuous calibration of a Na } \mathrm{Na}^{+} \mathrm{ISE} \\
\text { integrated in a patch to various salt solutions } \\
(0.1,1,10,100 \mathrm{mM}) \text { at a flow rate of } 5-10 \mu \mathrm{L} \\
\text { min. } \\
\text { All measurements performed with } \\
\text { commercial instrumentation and using an } \\
\text { in vitro fluidic system for artificial sweat } \\
\text { delivery to the patch }\end{array}$ & $\begin{array}{l}\text { Change in sensor response measured } \\
\text { when } \mathrm{K}^{+} \text {is added in a Na+ environment. }\end{array}$ & n.a. \\
\hline Kim 2018 [32] & 3 & PBS & $\begin{array}{l}\text { Single point calibration: response of the } \\
\text { glucose and alcohol biosensor tested in } \\
\text { response to increasing ethanol concentrations } \\
\text { tested with separate chronoamperometric } \\
\text { measurements of } 60 \mathrm{~s} \text {. }\end{array}$ & $\begin{array}{c}\text { Change in sensor response measured } \\
\text { when relevant electroactive species (glucose, } \\
\text { lactate, creatine, ascorbic acid, and uric acid) } \\
\text { were added to } 10 \times 10^{-3} \mathrm{~m} \text { ethanol. }\end{array}$ & $\begin{array}{l}\text { Repetitive measurements of } \\
\text { ethanol (left) and glucose (right). }\end{array}$ \\
\hline Gao 2016 [52] & 8 & PBS, artificial sweat & $\begin{array}{c}\text { Continuous calibration: the } \\
\text { chronoamperometric responses of the glucose } \\
\text { and lactate sensors and the open circuit } \\
\text { potential responses of the sodium and } \\
\text { potassium sensors to increasing } \\
\text { concentrations of the respective analyte } \\
\text { solutions in phosphate-buffered saline (PBS) } \\
\text { were measured. } \\
\text { Additional testing performed to evaluate the } \\
\text { influence of mechanical bending and using } \\
\text { artificial sweat diluting solution. }\end{array}$ & $\begin{array}{l}\text { Change in sensor response measured } \\
\text { when relevant electroactive species are added. } \\
\text { Shared solid-state } \mathrm{Ag} / \mathrm{AgCl} \text { or PVB reference } \\
\text { electrodes were used respectively for } \\
\text { metabolites and ions. Data recording was } \\
\text { paused for } 30 \text { s for the addition of each } \\
\text { analyte. }\end{array}$ & $\begin{array}{l}\text { Repetitive measurements } \\
\text { performed over a period of } 4 \\
\text { weeks. }\end{array}$ \\
\hline
\end{tabular}


Table 3. Cont.

\begin{tabular}{|c|c|c|c|c|c|}
\hline REF & Number of Sensors & $\begin{array}{l}\text { In Vitro Diluting } \\
\text { Solution Used }\end{array}$ & Calibration Protocol & Selectivity Test & Stability Test \\
\hline Gamella 2014 [38] & 10 & PBS & $\begin{array}{l}\text { Single point calibration using different } \\
\text { concentrations of ethanol in PBS with } \\
\text { temperature control. } \\
\text { Repeatability tested repeating the same } \\
\text { measurement on a single biodevice with } 10 \\
\text { different solutions. Reproducibility tested } \\
\text { repeating the same measurement on } 10 \\
\text { different biodevices }\end{array}$ & n.a. & $\begin{array}{l}\text { Five different biodevices stored } \\
\text { for } 2 \text { months in PBS and other } \\
\text { five biodevices under dry } \\
\text { conditions. }\end{array}$ \\
\hline
\end{tabular}

Table 4. Summary of in vivo characterization protocols.

\begin{tabular}{|c|c|c|c|c|c|}
\hline REF & Number of Subjects & $\begin{array}{l}\text { Ex Situ Analysis } \\
\text { Protocol }\end{array}$ & $\begin{array}{l}\text { In Situ Analysis } \\
\text { Protocol }\end{array}$ & Data Analysis & $\begin{array}{l}\text { Comparison with Other } \\
\text { Gold Standard Test Techniques }\end{array}$ \\
\hline Liang 2021 [49] & 1 & n.a. & $\begin{array}{l}\text { Task: three different phases, a } \\
\text { 5-min warming-up, 20-min } \\
\text { cycling, and a 5-min rest. }\end{array}$ & $\begin{array}{l}\text { Real-time analysis was performed on the } \\
\text { volunteers during working on a cycle } \\
\text { ergometer } \\
\text { with the device attached to the forearm } \\
\text { area by a transparent adhesive PU } \\
\text { membrane with a round hole for sweat } \\
\text { evaporation }\end{array}$ & $\begin{array}{l}\text { Only reference to standard } \mathrm{K}^{+} \text {level } \\
\text { from literature in serum }\end{array}$ \\
\hline Zhang 2021 [43] & 1 & $\begin{array}{l}\text { Ex situ (off-body) measurements } \\
\text { from a PBS with known }\left[\mathrm{K}^{+}\right] \\
\text {concentration value samples were } \\
\text { employed to verify the accuracy of } \\
\text { on-body measurements. }\end{array}$ & $\begin{array}{l}\text { Task: stationary cycling } \\
\text { real-time perspiration monitoring } \\
\text { on the } \\
\text { arm }\end{array}$ & $\begin{array}{l}\text { After properly connecting NFC and } \\
\text { pre-installed application, the PC displays } \\
\text { the sensor's real-time output potential. } \\
\text { Data are read from the FRAM, with the } \\
\text { ADC values and corresponding raw } \\
\text { voltages converted and displayed as }\left[\mathrm{K}^{+}\right] \\
\text {concentration values using ex situ } \\
\text { pre-calibration. }\end{array}$ & $\begin{array}{l}\text { No comparison with gold standard } \\
\text { techniques, but performance } \\
\text { comparison with that of } \\
\text { alternative sensors detailed in the } \\
\text { published scientific literature }\end{array}$ \\
\hline Vinoth 2021 [42] & 2 & $\begin{array}{l}\text { Sweat samples were collected } \\
\text { at two different intervals of } 15 \text { and } 30 \\
\text { min of stationary biking and } \\
\text { analyzed using several gold standard } \\
\text { techniques. }\end{array}$ & $\begin{array}{l}\text { Task: } 30 \text { min stationary biking } \\
\text { load is initially increased, then } \\
\text { maintained constant for up to } \\
\sim 23 \text { min, and } \\
\text { then decreased. }\end{array}$ & $\begin{array}{l}\text { The sweat secretion and subsequent } \\
\text { analysis of the data (real time presented) } \\
\text { were started after } 8-10 \text { min of exercise } \\
\text { activities. } \\
\text { Data obtained from in vivo calibrated } \\
\text { device were compared with ex situ } \\
\text { measurements. }\end{array}$ & $\begin{array}{l}\text { Comparison with results from } \\
\text { high-performance liquid } \\
\text { chromatography (HPLC), flame } \\
\text { atomic absorption spectrometry } \\
\text { (FAAS), and a pH meter. }\end{array}$ \\
\hline
\end{tabular}


Table 4. Cont.

\begin{tabular}{|c|c|c|c|c|c|}
\hline REF & Number of Subjects & $\begin{array}{l}\text { Ex Situ Analysis } \\
\text { Protocol }\end{array}$ & $\begin{array}{l}\text { In Situ Analysis } \\
\text { Protocol }\end{array}$ & Data Analysis & $\begin{array}{l}\text { Comparison with Other } \\
\text { Gold Standard Test Techniques }\end{array}$ \\
\hline Wenya 2019 [44] & 5 & n.a. & $\begin{array}{c}\text { Task: } 30 \mathrm{~min} \text { cycling } \\
\text { Data acquisition: real-time and } \\
\text { simultaneous on-body detection. }\end{array}$ & $\begin{array}{l}\text { The test button was then pressed down to } \\
\text { initiate the analysis, and results were } \\
\text { displayed on the screen of smartphone } \\
\text { after completion } \\
\text { of the analysis. }\end{array}$ & $\begin{array}{l}\text { Compared glucose detection } \\
\text { with HPLC results }\end{array}$ \\
\hline Zhang 2019 [34] & 2 & $\begin{array}{l}\text { Sweat samples were induced and } \\
\text { collected from volunteers, when } \\
\text { sitting in a sauna, for off-body } \\
\text { evaluation }\end{array}$ & n.a. & n.a. & $\begin{array}{l}\text { A commercial ISE (HORIBA } \\
\text { LAQUAtwin-Na-11) to measure } \mathrm{Na}^{+} \\
\text {concentration, and a commercial } \mathrm{pH} \\
\text { meter (HORIBA LAQUAtwinpH-22) } \\
\text { to measure } \mathrm{pH} \text {, }\end{array}$ \\
\hline Lu 2019 [47] & 1 & n.a. & $\begin{array}{c}\text { Task: } 2 \mathrm{~h} \text { of sport. } \\
\text { Data acquisition: real time } \\
\text { monitoring of glucose } / \mathrm{K}^{+} \text {and } \\
\mathrm{Na}^{+} \text {in sweat }\end{array}$ & $\begin{array}{c}\text { Only qualitative results and graphs } \\
\text { displayed }\end{array}$ & n.a. \\
\hline Sempionatto 2019 [48] & 3 & n.a. & $\begin{array}{l}\text { Task: } 50 \text { min cycling } \\
\text { Data acquisition: recorded in } \\
\text { real-time during a } 2000 \text { s exercise } \\
\text { activity }\end{array}$ & $\begin{array}{l}\text { Data transmitted and displayed using a } \\
\text { laptop and a homemade system control } \\
\text { developed in Matlab. } \\
\text { Only qualitative graphs of analytes } \\
\text { concentration during exercise time. }\end{array}$ & n.a. \\
\hline
\end{tabular}


Table 4. Cont.

\begin{tabular}{|c|c|c|c|c|c|}
\hline REF & Number of Subjects & $\begin{array}{l}\text { Ex Situ Analysis } \\
\text { Protocol }\end{array}$ & $\begin{array}{l}\text { In Situ Analysis } \\
\text { Protocol }\end{array}$ & Data Analysis & $\begin{array}{l}\text { Comparison with Other } \\
\text { Gold Standard Test Techniques }\end{array}$ \\
\hline Xu 2019 [29] & 1 & n.a. & $\begin{array}{l}\text { Task: running on the treadmill } \\
\text { Data acquisition: } 1 \text { per minute, } \\
\text { proximity of the smartphone }\end{array}$ & $\begin{array}{l}\text { Real-time data and real-time plots of ion } \\
\text { concentrations. The concentrations of } \\
\mathrm{Ca}^{2+} \text { and } \mathrm{Cl}^{-} \text {during the whole exercising } \\
\text { process could be calculated thanks to the } \\
\text { calibration performed in vitro. }\end{array}$ & $\begin{array}{l}\text { The detection results of the } \\
\text { electrochemical patch }(\mathrm{N}=5) \text { were } \\
\text { compared with laboratory reference } \\
\text { method, including atomic absorption } \\
\text { spectrophotometer and ion } \\
\text { chromatography. }\end{array}$ \\
\hline Tai 2018 [33] & 2 & $\begin{array}{l}\text { Human sweat samples collected } \\
\text { thanks to a pilocarpine } \\
\text { hydrogel-based iontophoresis from } \\
\text { subject wrist for } 30 \text { min or from the } \\
\text { forehead every } 5 \text { min during cycling } \\
\text { analyzed ex situ with commercial } \\
\text { potentiostat }\end{array}$ & $\begin{array}{l}\text { Task: subjects asked to consume a } \\
\text { single-shot espresso }(\approx 75 \mathrm{mg} \\
\text { caffeine), then rest for } 30 \mathrm{~min} \text {, and } \\
\text { then to begin cycling with the sensor } \\
\text { fixed around the subject's wrist with } \\
\text { a PDMS band. } \\
\text { Data acquisition: } 1 \text { measure every } 10 \\
\text { min }\end{array}$ & $\begin{array}{c}\text { Raw data was then transmitted } \\
\text { via Bluetooth wirelessly to a user } \\
\text { interface (CoolTerm serial-port terminal } \\
\text { application), normalized to a common } \\
\text { baseline current, and filtered (MATLAB } \\
\text { Hampel and Smooth functions) for } \\
\text { caffeine level monitoring on a computer. } \\
\text { Curve fitting was performed and plotted } \\
\text { as the dotted line (MATLAB Weibull } \\
\text { function). }\end{array}$ & n.a. \\
\hline Nyein 2018 [31] & $\begin{array}{l}2 \text { (sweat rate and } \mathrm{Na} \text { ) } \\
1 \text { (sweat rate, } \mathrm{K}, \mathrm{Cl} \text {, } \\
\mathrm{pH} \text { ) }\end{array}$ & n.a. & $\begin{array}{l}\text { Task: cycling on an ergometer, } \\
\text { constant power with the patch } \\
\text { around the wrist Data acquisition: } \\
\text { discrete measurement from } \\
\text { Macroduct every } 3 \text { min to } 4 \text { min, } \\
\text { continuous measurements performed } \\
\text { with customized electronics with } \\
\text { operating frequency } 100 \mathrm{kHz}\end{array}$ & $\begin{array}{l}\text { Qualitative comparison between the } 2 \\
\text { subjects tested for sweat rate and } \mathrm{Na}^{+} ; \\
\text {qualitative plots for } \mathrm{pH}, \mathrm{K}^{+}, \mathrm{Cl}^{-} \text {and } \\
\text { sweat rate to show possibility of multiple } \\
\text { sensing. Parameters extracted: } \\
\text { proportional trends, response time }\end{array}$ & $\begin{array}{l}\text { On-body performance of the sweat } \\
\text { rate sensor was validated } \\
\text { with the Macroduct which is a } \\
\text { standard sweat collection system } \\
\text { used in cystic fibrosis diagnosis. No } \\
\text { validation for } \mathrm{Na}^{+}, \mathrm{K}^{+}, \mathrm{Ph} \\
\text { measurements }\end{array}$ \\
\hline Alizadeh 2018 [35] & 1 & n.a. & $\begin{array}{l}\text { Task: high-intensity exercise on a } \\
\text { bicycle or a treadmill with the patch } \\
\text { on the subject's back, adjacent to the } \\
\text { spine on the latissimus dorsi muscle } \\
\text { and/or thoracolumbar fascia in the } \\
\text { region of the upper lumbar vertebra. } \\
\text { Data acquisition and transmission: } \\
\text { The sweat patch and associated } \\
\text { electronics module were monitored } \\
\text { remotely via Bluetooth for the } \\
\text { duration of the exercise sessions. } \\
\text { Sample rate: } 100 \mathrm{~Hz} \text {, then moving } \\
\text { averaged at } 15 \mathrm{~s}\end{array}$ & $\begin{array}{l}\text { All work was carried out under a scope of } \\
\text { work that was determined not to be } \\
\text { human subject testing (E\&I Institutional } \\
\text { Review Board). As a result of this process, } \\
\text { the data collected during on-body was } \\
\text { specifically not calibrated to prevent the } \\
\text { generation of physiologic data on the } \\
\text { subject, thus all data for on-body testing } \\
\text { is presented in the raw form (mV). }\end{array}$ & n.a. \\
\hline
\end{tabular}
averaged at $15 \mathrm{~s}$ 
Table 4. Cont.

\begin{tabular}{|c|c|c|c|c|c|}
\hline REF & Number of Subjects & $\begin{array}{l}\text { Ex Situ Analysis } \\
\text { Protocol }\end{array}$ & $\begin{array}{l}\text { In Situ Analysis } \\
\text { Protocol }\end{array}$ & Data Analysis & $\begin{array}{l}\text { Comparison with Other } \\
\text { Gold Standard Test Techniques }\end{array}$ \\
\hline Kim 2018 [32] & 11 & n.a. & $\begin{array}{l}\text { Sweat induced with IP with the sensor } \\
\text { placed onto the deltoid. } \\
\text { Task: initial baseline measurement, } \\
\text { subjects sugar-rich food with an alcoholic } \\
\text { beverage (12 oz. of beer or } 5 \text { oz. of table } \\
\text { wine), wait for } 15 \text { min, second } \\
\text { measurement. The same protocol } \\
\text { repeated with varying chronologies of } \\
\text { food/alcohol consumption. } \\
\text { Data Acquisition: flexible PCB board was } \\
\text { connected to the tattoo using magnets to } \\
\text { perform discrete measurements every } 20 \\
\text { min. }\end{array}$ & $\begin{array}{l}\text { Discrete values acquired compared } \\
\text { among the different conditions tested. } \\
\text { The correlation blood level and sweat } \\
\text { current signal for both glucose and } \\
\text { alcohol was quantitatively described } \\
\text { using } \mathrm{R}^{2} \text { parameter, }\end{array}$ & $\begin{array}{l}\text { Immediately before starting the } \\
\text { experiment, blood glucose and } \\
\text { alcohol levels were measured } \\
\text { using commercial glucose strips } \\
\text { (Accu-Chek Aviva Plus) and a } \\
\text { commercial FDA-approved } \\
\text { breath } \\
\text { analyzer (Alcovisor Mars } \\
\text { Breathalyzer, Hong Kong) to } \\
\text { validate the } \\
\text { sensor performance. }\end{array}$ \\
\hline Gao 2016 [52] & 26 & $\begin{array}{c}\text { Ex situ sensor performance } \\
\text { conducted by testing sweat samples } \\
\text { collected from the subjects' foreheads. } \\
\text { Sweat } \\
\text { samples were collected every } 2-4 \text { min } \\
\text { by scratching cleaned foreheads with } \\
\text { microtubes }\end{array}$ & $\begin{array}{l}\text { Task: three trials: constant workload cycle } \\
\text { ergometry (14 subj), graded workload } \\
\text { cycle } \\
\text { Ergometry ( } 7 \text { subj), and outdoor running } \\
\text { (12 subj). An ergometer providing } \\
\text { real-time monitoring of heart rate, oxygen } \\
\text { consumption, pulmonary ventilation and } \\
\text { power output was used. The FISAs were } \\
\text { packaged inside traditional sweatbands } \\
\text { during the indoor and outdoor trials. The } \\
\text { sensor arrays were calibrated, and worn } \\
\text { on cleaned foreheads and wrists. }\end{array}$ & $\begin{array}{l}\text { Due to differences in absolute potential } \\
\text { values for ISEs in the same solution. } \\
\text { Therefore, one-point calibration in a } \\
\text { standard solution containing } 1 \mathrm{mM} \mathrm{KCl} \\
\text { and } 10 \mathrm{mM} \mathrm{NaCl} \text { was performed for } \mathrm{Na}^{+} \\
\text {and } \mathrm{K}^{+} \text {sensors before each use. The } \\
\text { measured potential of ISEs in the } \\
\text { standard solution was then set to zero by } \\
\text { the microcontroller. }\end{array}$ & $\begin{array}{l}\text { The accuracy of on-body } \\
\text { measurements was verified } \\
\text { through the comparison of } \\
\text { on-body sensor readings from } \\
\text { the forehead with ex situ } \\
\text { (off-body) measurements from } \\
\text { collected } \\
\text { sweat samples, no additional } \\
\text { method used. }\end{array}$ \\
\hline Gamella 2014 [38] & 40 & n.a. & $\begin{array}{l}\text { Sweat was induced by an IP system } \\
\text { (Macroduct) for } 5 \text { min. } \\
\text { Task: alcoholic beverage assumption in } \\
5-10 \text { min (gin, rum or whisky mixed with } \\
\text { a cola or juice soft drink) then alcohol } \\
\text { monitoring following two protocols: } \\
\text { continuous mode } \rightarrow \text { biodevice on the } \\
\text { skin after sweat generation, continuous } \\
\text { measurement from } 30 \text { min to } 2 \text { h. } \\
\text { single measurement mode } \rightarrow \text { placing the } \\
\text { biodevice in contact with the skin for } 5 \\
\text { min every } 15 \text { min. }\end{array}$ & $\begin{array}{l}\text { Data analyzed by computing the } \\
\text { correlation between the ethanol content in } \\
\text { sweat and in blood by gas } \\
\text { chromatography, the correlation between } \\
\text { BAC and the current measured in sweat } \\
\text { with the biodevice time response and } \\
\text { maximum ethanol concentration with } \\
\text { respect to blood results. }\end{array}$ & $\begin{array}{l}\text { Reference standard blood } \\
\text { analysis using gas } \\
\text { chromatography method was } \\
\text { performed } 30 \text { min after alcohol } \\
\text { intake and every } 10 \text { min or after } \\
\text { the single measurement. }\end{array}$ \\
\hline
\end{tabular}


Table 5. Summary of electronics specific features.

\begin{tabular}{|c|c|c|c|c|c|}
\hline REF & $\begin{array}{c}\text { Electronics Substrate } \\
\text { Material }\end{array}$ & Electronics Power Supply & Key Element Blocks & Data Transmission Methods & $\begin{array}{l}\text { Additional Filtering Circuits } \\
\text { Integrated, Processing } \\
\text { Algorithm }\end{array}$ \\
\hline Liang 2021 [49] & Flexible РСВ & $\begin{array}{l}\text { Lithium-polymer rechargeable } \\
\text { battery of } 50 \mathrm{mAh} \text {; measured average } \\
\text { current consumption of the entire } \\
\text { system during operation is } 1-2 \mathrm{~mA} \\
\text { (depends on the Bluetooth data } \\
\text { transmission frequency), which } \\
\text { enables prolonged test. }\end{array}$ & $\begin{array}{l}\text { voltage follower circuit with an } \\
\text { operational amplifier interface with } \\
\text { electrodes; microcontroller; 12-bit ADC; } \\
\text { 8-KB RAM;128-KB Flash; I2C interface } \\
\text { and a leading RF transceiver was } \\
\text { embedded. }\end{array}$ & Bluetooth Low Energy & $\begin{array}{l}\text { The output of the voltage } \\
\text { follower circuit is followed by an } \\
\text { RC low-pass filter to minimize } \\
\text { the noise and interference in the } \\
\text { measurements. The potential of } \\
\text { the reference electrode, from a } \\
\text { voltage divider network, is } \\
\text { constant and then digitized and } \\
\text { recorded using the ADC. }\end{array}$ \\
\hline Zhang 2021 [43] & $\begin{array}{l}\text { Copper and polyimide } \\
\text { flexible film + PDMS cover }\end{array}$ & $\begin{array}{l}\text { Battery-free, power harvested from } \\
\text { smartphone thanks to Near Field } \\
\text { Communication interface chip }\end{array}$ & $\begin{array}{l}\text { The SD14 module of the integrated NFC } \\
\text { chip is a multi-channel sigma-delta } \\
\text { analog-to-digital converter with up to } 14 \\
\text { bits of resolution integrated into the NFC } \\
\text { chip consisting of a programable gain } \\
\text { amplifier (PGA) and a sigma-delta } \\
\text { analog-to-digital converter (ADC). The } \\
\text { output of the [K } \mathrm{K}^{+} \text {] sensor was read } \\
\text { through a 14-bit ADC convertor. }\end{array}$ & $\begin{array}{l}\text { Near Field Communication (NFC). } \\
\text { The core of an integrated circuit } \\
\text { communicates with other modules } \\
\text { via a memory data bus and a memory } \\
\text { address bus. Instructions and data } \\
\text { are sent from the smartphone to the } \\
\text { RFID chip through the ISO15693 } \\
\text { analog front end and decoded } \\
\text { through the ISO15693 decoding } \\
\text { module. }\end{array}$ & $\begin{array}{l}\text { The smartphone application was } \\
\text { developed based on an Android } \\
\text { studio software program that } \\
\text { displays the }\left[\mathrm{K}^{+}\right] \text {concentration } \\
\text { by reading and calibrating the } \\
\text { ADC's output voltage. }\end{array}$ \\
\hline
\end{tabular}


Table 5. Cont.

\begin{tabular}{|c|c|c|c|c|c|}
\hline REF & $\begin{array}{l}\text { Electronics Substrate } \\
\text { Material }\end{array}$ & Electronics Power Supply & Key Element Blocks & Data Transmission Methods & $\begin{array}{l}\text { Additional Filtering Circuits } \\
\text { Integrated, Processing } \\
\text { Algorithm }\end{array}$ \\
\hline Wenya 2019 [44] & Standard rigid $\mathrm{PCB}$ & n.a. & $\begin{array}{l}\text { Signal transduction, conditioning, } \\
\text { processing, I-V inverter; Transimpedance } \\
\text { amplifier; Differential amplifier; ADC } \\
\text { microcontroller; }\end{array}$ & Bluetooth low energy (BLE) & Low-pass filter \\
\hline Zhang 2019 [34] & Standard rigid $\mathrm{PCB}$ & $\begin{array}{l}\text { Battery-free, power harvested from } \\
\text { smartphone thanks to Near Field } \\
\text { Communication interface chip }\end{array}$ & $\begin{array}{l}\text { Signal transduction obtained with } \\
\text { 3D-EMG ISFETs in an application-specific } \\
\text { integrated circuit, a 16:1 multiplexer, } \\
\text { 12-bit ADC, microcontroller }\end{array}$ & Near Field Communication (NFC) & n.a. \\
\hline Lu 2019 [47] & $\begin{array}{l}\text { Flexible polyethylene (PE) } \\
\text { film }\end{array}$ & n.a. & $\begin{array}{l}\text { ADC, RC oscillating circuit, } \\
\text { microcontroller }\end{array}$ & $\begin{array}{l}\text { WiFi module provides a way to allow } \\
\text { cached data in CPU transmit to } \\
\text { Mobile APP. }\end{array}$ & $\begin{array}{l}\text { Signal from compensation } \\
\text { electrodes used to reduce noise } \\
\text { from unspecific responses }\end{array}$ \\
\hline Sempionatto 2019 [48] & Flexible PDMS & $\begin{array}{l}\text { Li-ion rechargeable battery }(3.0 \mathrm{~V}) \\
\text { with } 100 \text { mAh capacitance }\end{array}$ & $\begin{array}{l}\text { Voltage follower circuit, ADC, } \\
\text { microcontroller }\end{array}$ & Bluetooth low energy (BLE) & n.a. \\
\hline Bandodkar 2019 [45] & Copper-on-polyimide & $\begin{array}{l}\text { Battery free, power harvested from } \\
\text { smartphone thanks to near field } \\
\text { communication interface chip; }\end{array}$ & $\begin{array}{l}\text { Simple voltage-follower design, analog } \\
\text { front-end independent from voltage } \\
\text { supply thanks to zero-crossover } \\
\text { operational amplifier, microcontroller and } \\
\text { NFC front-end combination, various } \\
\text { passive resistor and capacitor } \\
\text { components using low-temperature } \\
\text { solder paste. }\end{array}$ & Near Field Communication (NFC) & $\begin{array}{l}\text { High-frequency filter that } \\
\text { eliminates fluctuations } \\
\text { introduced by the electric field of } \\
\text { the primary NFC antenna. }\end{array}$ \\
\hline Xu 2019 [29] & $\begin{array}{l}\text { Ultrathin flexible } \\
\text { polyimide }\end{array}$ & $\begin{array}{l}\text { Battery-free, power harvested from } \\
\text { smartphone thanks to Near Field } \\
\text { Communication interface chip; }\end{array}$ & $\begin{array}{l}\text { Analog front ends, voltage stabilizers, } 3 \\
\text { ADCs, microcontroller }\end{array}$ & Near field communication (NFC) & $\begin{array}{l}\text { Bias circuits, voltage buffer, and } \\
\text { low-pass filter included in the } \\
\text { analog front end }\end{array}$ \\
\hline Tai 2018 [33] & Standard rigid $\mathrm{PCB}$ & $\begin{array}{l}\text { Single rechargeable lithium-ion } \\
\text { polymer battery }(3.7 \mathrm{~V}) \text {, to power: } \\
\text { the digital component of the circuit } \\
\text { and the analog portion of the circuit } \\
\text { at } 5.0 \mathrm{~V} \text {, achieved with DC-DC } \\
\text { converter to boost up voltage } \\
\text { the Bluetooth module at } 3.3 \mathrm{~V} \text {, using } \\
\text { only a low-dropout voltage regulator }\end{array}$ & $\begin{array}{l}\text { 16-bit DAC. low-pass transimpedance } \\
\text { amplifiers, 16-bit ADC, microcontroller }\end{array}$ & Bluetooth low energy (BLE) & $\begin{array}{l}\text { Fourth-order Sallen-Key } \\
\text { low-pass filter }\end{array}$ \\
\hline
\end{tabular}


Table 5. Cont.

\begin{tabular}{|c|c|c|c|c|c|}
\hline REF & $\begin{array}{c}\text { Electronics Substrate } \\
\text { Material }\end{array}$ & Electronics Power Supply & Key Element Blocks & Data Transmission Methods & $\begin{array}{l}\text { Additional Filtering Circuits } \\
\text { Integrated, Processing } \\
\text { Algorithm }\end{array}$ \\
\hline Nyein 2018 [31] & Standard rigid PCB & $\begin{array}{c}\text { Rechargeable lithium-ion battery ( } 3.7 \\
\text { V) }\end{array}$ & $\begin{array}{l}\text { (1) For impedance measurement high } \\
\text { precision impedance converter, on-chip } \\
\text { ADC } \\
\text { (2) For the open-circuit potential } \\
\text { measurement, voltage buffer provides a } \\
\text { midrail reference voltage, 16-bit ADC, } \\
\text { microcontroller. }\end{array}$ & Bluetooth low energy (BLE) & $\begin{array}{l}\text { Fourth-order Sallen-Key } \\
\text { low-pass filter. Discrete Fourier } \\
\text { transform (DFT) algorithm is } \\
\text { used for impedance calculation. }\end{array}$ \\
\hline Kim 2018 [32] & Polyimide & $\begin{array}{c}\text { CR2032 Lithium } \\
\text { coin battery, with power levels } 30 \text { and } \\
6 \mathrm{~mW} \text { in iontophoretic and } \\
\text { amperometric } \\
\text { phases, respectively }\end{array}$ & $\begin{array}{l}\text { Proprietary system-on-chip device: } \\
\text { configurable analog front end } \\
\text { potentiostat, several DC-DC converters } \\
\text { for voltage supply regulations to generate } \\
\text { reference potentials, a 3-terminal } \\
\text { adjustable current source to provide } \\
\text { iontophoretic current }\end{array}$ & Bluetooth low energy (BLE) & $\begin{array}{l}\text { A set of high voltage } \\
\text { switches to switch between } \\
\text { glucose and } \\
\text { alcohol sensing, as well as to } \\
\text { enter a high-impedance state } \\
\text { during iontophoretic processing. }\end{array}$ \\
\hline Gao 2016 [52] & Flexible РСВ & $\begin{array}{c}\text { Rechargeable lithium-ion polymer } \\
\text { battery }(3.7 \mathrm{~V}, 105-\mathrm{mAh})\end{array}$ & $\begin{array}{l}\text { Programmable microcontroller through } \\
\text { an in-circuit serial programming interface. } \\
\text { The conditioning path for each sensor } \\
\text { was implemented in relation to the } \\
\text { corresponding sensing mode. In the case } \\
\text { of the amperometric-based glucose and } \\
\text { lactate sensors, the originally generated } \\
\text { signal was in the form of electrical } \\
\text { current. }\end{array}$ & Bluetooth & $\begin{array}{c}\text { All the analog signal } \\
\text { conditioning paths concluded } \\
\text { with a corresponding unity gain } \\
\text { four-pole low-pass filter, each } \\
\text { with a - -3-dB frequency at } 1 \mathrm{~Hz} \\
\text { to minimize the noise and } \\
\text { interference in our measurements. } \\
\text { A mobile application (the } \\
\text { Perspiration } \\
\text { Analysis App) was designed to } \\
\text { accompany the FISA and to } \\
\text { provide a user-friendly interface } \\
\text { for data display and aggregation }\end{array}$ \\
\hline Gamella 2014 [38] & Standard rigid PCB & $\begin{array}{l}\text { Battery-powered (V not available), } \\
\text { battery life } 6-8 \mathrm{~h}\end{array}$ & $\begin{array}{c}\text { PCB, high current amplification circuit, } \\
\text { I-V current, filtering circuit. AD8542, PIC } \\
\text { 16F870, display LCD }\end{array}$ & $\begin{array}{l}\text { Not specified, provided information } \\
\text { only about results displayed on LCD }\end{array}$ & Noise removal \\
\hline
\end{tabular}


Table 6. Summary of in vivo characterization protocols.

\begin{tabular}{|c|c|c|c|c|c|c|c|c|c|c|}
\hline REF & Sensitivity & $\begin{array}{c}\text { Limit of } \\
\text { Detection }\end{array}$ & $\begin{array}{l}\text { Accuracy (Error } \\
\text { Analysis) }\end{array}$ & Selectivity & Repeatability & Reproducibility & Stability & Linearity & Response Time & $\begin{array}{l}\text { Recovery } \\
\text { Values }\end{array}$ \\
\hline $\begin{array}{c}\text { Liang } 2021 \\
{[49]}\end{array}$ & $61.79 \mathrm{mV} / \mathrm{dec}$ & n.a. & $\begin{array}{l}\text { The final sweat } \\
\text { potassium level is } \\
\text { similar to the serum } \\
\text { one, with a slightly } \\
\text { broader range } \\
\text { (approximately 2-8 } \\
\text { mM). }\end{array}$ & $\begin{array}{c}\text { Negligible } \\
\text { interference of other } \\
\text { ions and metabolites } \\
\text { to the response of } \\
\text { the K selective } \\
\text { sensor } \\
\text { (approximately } 1 \\
\text { mV). }\end{array}$ & n.a. & $\begin{array}{c}\text { RSD: } \\
0.38 \% \text {;however, } \\
\text { absolute } \\
\text { potential values } \\
\text { for sensors differ } \\
\text { in the same } \\
\text { concentration of } \\
\text { a solution, so } \\
\text { calibration in } \\
\text { standard } \\
\text { solution, } 1 \mathrm{mM} \\
\mathrm{KCl} \text {, is necessary } \\
\text { before use. }\end{array}$ & $\begin{array}{c}\text { The sensor has a } \\
\text { stable } \\
\text { sensitivity. }\end{array}$ & $R^{2}=0.999$ & $\begin{array}{l}<5 \mathrm{~s} \text { when } \\
\text { concentration is } \\
\text { doubled }\end{array}$ & n.a. \\
\hline $\begin{array}{c}\text { Zhang } 2021 \\
\text { [43] }\end{array}$ & $\begin{array}{l}63 \mathrm{mV} / \mathrm{dec} \\
\text { amplified to } \\
173 \mathrm{mV} / \mathrm{dec} \\
\text { using an NFC } \\
\text { amplification }\end{array}$ & n.a. & $\begin{array}{l}\text { Only reported a } \\
\text { table comparing } \\
\text { output from sensor } \\
\text { and from complete } \\
\text { system }\end{array}$ & Excellent & $\begin{array}{c}\text { RSD } \\
\text { performance of } \\
3.33 \% \text { (sensor) } \\
\text { and } 2.67 \% \\
\text { (system) in four } \\
\text { measurements }\end{array}$ & $\begin{array}{l}\text { Good } \\
\text { reproducibility }\end{array}$ & n.a. & $\begin{array}{l}\text { Linear range } \\
1-32 \mathrm{mM}\end{array}$ & $2 \mathrm{~s}$ & From 92 to $97 \%$ \\
\hline
\end{tabular}


Table 6. Cont.

\begin{tabular}{|c|c|c|c|c|c|c|c|c|c|c|}
\hline REF & Sensitivity & $\begin{array}{l}\text { Limit of } \\
\text { Detection }\end{array}$ & $\begin{array}{l}\text { Accuracy (Error } \\
\text { Analysis) }\end{array}$ & Selectivity & Repeatability & Reproducibility & Stability & Linearity & Response Time & $\begin{array}{c}\text { Recovery } \\
\text { Values }\end{array}$ \\
\hline $\begin{array}{c}\text { Wenya } 2019 \\
{[44]}\end{array}$ & $\begin{array}{c}\text { Glu: } 6.3 \\
\mathrm{nA} / \mu \mathrm{M} \\
\mathrm{Lac}: 174.0 \\
\mathrm{nA} / \mathrm{mM} \\
\mathrm{AA}: 22.7 \\
\mathrm{nA} / \mu \mathrm{M} \\
\mathrm{UA}: 196.6 \\
\mathrm{nA} / \mu \mathrm{M} \\
\mathrm{Na}^{+}: 51.8 \\
\mathrm{mV} / \text { decade } \\
\mathrm{K}^{+}: 31.8 \\
\mathrm{mV} / \text { decade }\end{array}$ & $\begin{array}{c}\text { Glu: } 5 \mu \mathrm{M} \\
\text { Lac: } 0.5 \mathrm{mM} \\
\text { AA: } 1 \mu \mathrm{M} \\
\mathrm{UA:} 0.1 \mu \mathrm{M} \\
\mathrm{Na}^{+}: 1 \mathrm{mM} \\
\mathrm{K}^{+}: 0.5 \mathrm{mM}\end{array}$ & n.a. & $\begin{array}{l}\text { Compared with the } \\
\text { signal of the } \\
\text { targeted molecule, } \\
\text { no noticeable } \\
\text { interference signals } \\
\text { were detected, } \\
\text { implying the good } \\
\text { selectivity of each } \\
\text { sensor, which is } \\
\text { beneficial to the } \\
\text { construction of } \\
\text { a multiplex sensing } \\
\text { system. }\end{array}$ & n.a. & $\begin{array}{c}\text { RSDs are } 3.6 \% \\
\text { for glucose, } 4.2 \% \\
\text { for lactate, } \\
2.8 \% \text { for AA, } \\
3.9 \% \text { for } \mathrm{UA}, \\
8.2 \% \text { for } \mathrm{Na}^{+} \\
\text {and } 7.5 \% \text { for } \mathrm{K}^{+}\end{array}$ & $\begin{array}{c}\begin{array}{c}\text { Negligible } \\
\text { changes }\end{array} \\
\text { over } 4 \text { weeks } \\
\text { with RSDs of } \\
6.4 \% \\
\text { for glucose, } 5.4 \% \\
\text { for lactate, } 0.8 \% \\
\text { for AA, } 3.4 \% \text { for } \\
\text { UA, } 2.9 \% \text { for } \\
\mathrm{Na}^{+} \\
\text {and } 1.8 \% \text { for } \mathrm{K}^{+}\end{array}$ & $\begin{array}{c}\text { Glu: from } 25 \text { to } \\
300 \mu \mathrm{M} \\
\text { Lac: from } 5 \text { to } 35 \\
\mathrm{mM} \\
\text { AA: from } 20 \text { to } \\
300 \mu \mathrm{M} \\
\mathrm{UA} \text { : from } 2.5 \text { to } \\
115 \mu \mathrm{M} \\
\mathrm{Na}^{+}: 5 \text { to } 100 \\
\mathrm{mM} \\
\mathrm{K}^{+}: 1.25 \text { to } \\
40 \mathrm{mM}\end{array}$ & n.a. & n.a. \\
\hline $\begin{array}{c}\text { Zhang } 2019 \\
\text { [34] }\end{array}$ & $\begin{array}{c}\mathrm{Na}^{+}:-56.9 \\
\mathrm{mV} / \mathrm{dec} \mathrm{X} \\
\mathrm{K}^{+}:-48.1 \\
\mathrm{mV} / \mathrm{dec} \mathrm{X} \\
\mathrm{Ca}^{2+}:-25.7 \\
\mathrm{mV} / \\
\operatorname{decX}\end{array}$ & n.a. & $\begin{array}{c}\text { Compared to } \\
\text { commercial } \mathrm{Na}^{+} \\
\text {meter and } \mathrm{pH} \text { meter } \\
\text { maximum deviation } \\
\text { of maximum } \\
12 \% \text { and } 2.3 \% \text {, } \\
\text { respectively. }\end{array}$ & $\begin{array}{c}\text { Selectivity reported } \\
\text { as cross-sensitivities } \\
\text { in mV/decX: } \\
\text { for } \mathrm{Na}^{+} 2.7 \mathrm{vs} . \mathrm{H}, 2.3 \\
\text { vs. } \mathrm{K}^{+}, 2.8 \mathrm{vs} \mathrm{Ca}^{+} \text {; } \\
\text { for } \mathrm{K}^{+} 6.4 \mathrm{vs} . \mathrm{H}, 8.6 \\
\text { vs } \mathrm{Na}^{+}, 0.8 \text { vs. } \mathrm{Ca}^{2+} \text {; } \\
\text { for } \mathrm{Ca}^{2+} 0.3 \mathrm{vs} . \mathrm{H}, \\
-2.4 \text { vs. } \mathrm{Na}^{+},-6.3 \\
\text { vs. } \mathrm{K}^{+}\end{array}$ & n.a. & $\begin{array}{l}\text { RSD } 9.3 \% \text { for } \\
\text { our } \mathrm{Na}^{+} \text {sensors, } \\
\text { and } 2.3 \% \text { for our } \\
\text { pH sensors }\end{array}$ & $\begin{array}{l}\text { Maximum } \\
\text { time-dependent } \\
\text { standard } \\
\text { deviation of } \\
1.95 \% \text { in } \\
\text { 3D-EMG-Na } \\
\text { sensor, and } \\
1.36 \% \text { in the } \\
\text { 3D-EMG-pH } \\
\text { sensor, with } \\
\text { respect to their } \\
\text { average value }\end{array}$ & n.a. & $\begin{array}{l}\text { Fast response } \\
\qquad(<5 \mathrm{~s})\end{array}$ & n.a. \\
\hline Lu 2019 [47] & $\begin{array}{c}\text { Glu: } 0.5 \\
\mu \mathrm{A} / \mu \mathrm{M} \\
() \\
\mathrm{Na}^{+}: 2.25 \\
\mu \mathrm{A} / \mathrm{mM} \\
(0.031 \mathrm{nF} / \mathrm{mM} \\
\text { capacitive } \\
\text { mode }) \\
\mathrm{K}^{+}: 4.25 \\
\mu \mathrm{A} / \mathrm{mM} \\
(0.056 \mathrm{nF} / \mathrm{mM} \\
\text { capacitive } \\
\text { mode) }\end{array}$ & Glu: $10 \mu \mathrm{M}$ & n.a. & n.a. & n.a. & n.a. & $\begin{array}{l}\text { Stable potential } \\
\text { windows } \\
\text { between } 0 \text { and } 1 \\
\text { V; after } 20,000 \\
\text { cycles, the } \\
\text { capacitance } \\
\text { retention } \\
\text { still retained } \\
\text { about } 96.6 \% \text { of } \\
\text { its initial value, } \\
\text { suggesting good } \\
\text { cycling } \\
\text { stability }\end{array}$ & $\begin{array}{c}\text { The response } \\
\text { currents rise up } \\
\text { linearly with the } \\
\text { increase in } \\
{\left[\mathrm{Na}^{+}\right] \text {from } 10 \text { to }} \\
160 \mathrm{mM} \text { and of } \\
{\left[\mathrm{K}^{+}\right] \text {from } 1 \mathrm{mM}} \\
\text { to } 16 \mathrm{mM} \\
\text { Glu from } 5-25 \\
\mathrm{mM}\end{array}$ & n.a. & n.a. \\
\hline
\end{tabular}


Table 6. Cont.

\begin{tabular}{|c|c|c|c|c|c|c|c|c|c|c|}
\hline REF & Sensitivity & $\begin{array}{c}\text { Limit of } \\
\text { Detection }\end{array}$ & $\begin{array}{c}\text { Accuracy (Error } \\
\text { Analysis) }\end{array}$ & Selectivity & Repeatability & Reproducibility & Stability & Linearity & Response Time & $\begin{array}{c}\text { Recovery } \\
\text { Values }\end{array}$ \\
\hline $\begin{array}{c}\text { Sempionatto } \\
2019[48]\end{array}$ & $\begin{array}{l}\mathrm{K}^{+} \text {: slope } 60 \pm \\
12 \mathrm{mV} \\
\mathrm{Na}^{+} \text {: slope } 46 \\
\quad \pm 7 \mathrm{mV}\end{array}$ & n.a. & n.a. & $\begin{array}{c}\text { Negligible } \\
\text { interference from } \\
\text { potential co-existing } \\
\text { ions }\left(\mathrm{Ca}^{2+} \text { and }\right. \\
\left.\mathrm{Mg}^{2+}\right) .\end{array}$ & $\begin{array}{l}\text { Response to } 10 \\
\text { mM ion } \\
\text { concentration in } \\
\text { water using } 10 \\
\text { repetitive flow } \\
\text { injections } \\
\text { provided similar } \\
\quad \text { results }\end{array}$ & n.a. & $\begin{array}{l}\text { After a week change } \\
\text { of } 23 \% \text { for } \mathrm{Na}^{+} \text {and } \\
\text { of } 19 \% \text { for } \mathrm{K}^{+}\end{array}$ & $\begin{array}{c}\text { linearity of } \mathrm{r}= \\
0.96 \text { for } \mathrm{K}^{+} \mathrm{r}= \\
0.98 \text { for } \mathrm{Na}^{+}\end{array}$ & $\begin{array}{l}\text { It takes over } 5 \\
\text { min for the } \\
\text { reservoir to be } \\
\text { filled with } \\
\text { sweat, during } \\
\text { which only the } \\
\text { background } \\
\text { signal is } \\
\text { recorded. }\end{array}$ & n.a. \\
\hline $\begin{array}{c}\text { Bandodkar } \\
2019 \text { [45] }\end{array}$ & $\begin{array}{c}\text { Lac: } 124 \\
\mathrm{mV} /\left(\mathrm{mM}^{*} \mathrm{~cm}^{2}\right) \\
\text { Glu: } 5.4 \\
\mathrm{mV} /\left(\mathrm{mM}^{*} \mathrm{~cm}^{2}\right)\end{array}$ & $\begin{array}{l}\text { Lac: } 2.1 \mathrm{mM} \\
\text { Glu: } 43 \mu \mathrm{M}\end{array}$ & $\begin{array}{l}\text { Qualitative } \\
\text { comparison between } \\
\text { outputs from } \\
\text { proposed sensor and } \\
\text { conventional } \\
\text { technique }\end{array}$ & $\begin{array}{c}\text { Increment in signal } \\
\text { due to interferents } \\
\sim 4 \% \rightarrow \mathrm{Lac} \\
\sim 12 \% \rightarrow \mathrm{Glu} \\
\text { Interference of } \mathrm{pH} \\
\text { changes: } \\
\text { Lac: } \mathrm{SD} 1 \mathrm{mV}, \\
\text { maximum error of } \\
\sim 1.3 \mathrm{mM} \\
\text { Glu: }\end{array}$ & $\begin{array}{l}\text { Maximum RSD } \\
\sim 6 \% \text { for Lac } \\
\sim 4 \% \text { for Glu }\end{array}$ & $\underset{\sim 5.5 \%}{\operatorname{maximum} \mathrm{RSD},}$ & $\begin{array}{l}\text { The data reveal } \\
\text { stable sensor } \\
\text { response } \\
\text { throughout the first } \\
6 \text { days (maximum } \\
\text { RSD of } 1.9 \text { and } 4.4 \% \\
\text { for glucose } \\
\text { and lactate sensors, } \\
\text { respectively) and a } \\
\sim 13 \text { and } \sim 23 \% \text { Signal } \\
\text { decrement } \\
\text { for glucose and } \\
\text { lactate sensors, } \\
\text { respectively, by } 8 \\
\text { days. }\end{array}$ & $\begin{array}{l}\text { The output } \\
\text { voltage of the } \\
\text { biofuel } \\
\text { cell-based } \\
\text { sensors } \\
\text { increases } \\
\text { linearly with } \\
\text { increasing load. }\end{array}$ & $\begin{array}{c}\text { Glu: signal } \\
\text { stabilizes within } \\
10 \text { to } 20 \mathrm{~s} . \\
\text { Lac: signal } \\
\text { stabilizes within } \\
300 \mathrm{~s}\end{array}$ & n.a. \\
\hline Xu 2019 [29] & $\begin{array}{l}\mathrm{Ca}^{2+}: 29.24 \\
\mathrm{mV} / \text { decade } \\
\mathrm{Cl}^{-}:-51.02 \\
\mathrm{mV} / \text { decade }\end{array}$ & $\begin{array}{c}\mathrm{Ca}^{2+}: \\
\text { LLOD } 5 \mu \mathrm{M} \\
\text { ULOD } 0.5 \mathrm{M} \\
\mathrm{Cl}^{-}: \\
\text {LLOD } 500 \mu \mathrm{M} \\
\text { ULOD }>1 \mathrm{M}\end{array}$ & $\begin{array}{c}\text { Relative errors } \\
\text { between the average } \\
\text { sensor } \\
\text { readings and the } \\
\text { real values acquired } \\
\text { by AAS in serum, } \\
\text { urine, sweat, } \\
\text { and tear }(1.57 \% \text {, } \\
3.58 \%, 4.91 \% \text {, and } \\
1.32 \% \text {, respectively } \\
\text { for } \mathrm{Ca}^{2+} \text { and } \\
1.33 \%, 1.43 \%, 1.53 \% \text {, } \\
\text { and } 1.15 \% \text {, for } \mathrm{Cl}^{-} \text {) }\end{array}$ & $\begin{array}{l}\text { "Good selectivity" } \\
\text { stated from } \\
\text { negligible response } \\
\text { to other anions or } \\
\text { cations tested }\end{array}$ & $\begin{array}{c}\mathrm{Ca}^{2+} \text { sensors: } \\
\mathrm{RSD}=7.8 \% \\
\mathrm{Cl}^{-} \text {sensors: } \\
\mathrm{RSD}=13.8 \%\end{array}$ & n.a. & $\begin{array}{c}\mathrm{Ca}^{2+}: \text { average } \\
\text { decreasing rate of } \\
0.90 \mathrm{mV} / \mathrm{h} \\
\mathrm{Cl}^{-}: \text {average } \\
\text { decreasing rate of } \\
1.50 \mathrm{mV} / \mathrm{h} \text { during } \\
\text { the first ten } \\
\text { hours. Then, the } \\
\text { output became } \\
\text { stable and decreased } \\
\text { to } 2.15 \mathrm{mV} \text { during } \\
\text { the rest sixty-two } \\
\text { hours }\end{array}$ & $\begin{array}{c}\mathrm{Ca}^{2+}: \mathrm{R}^{2} \text { of } \\
0.99832 \\
\text { linear range: } \\
10^{-5} \text { to } 10^{-1} \mathrm{M} \\
\mathrm{Cl}^{-}: \mathrm{R}^{2} \text { of } \\
0.99983 \\
\text { linear range: } \\
\text { from } 10^{-2} \text { to } 1 \\
\mathrm{M}\end{array}$ & $\begin{array}{c}\mathrm{Ca}^{2+}: 20 \mathrm{sCl}^{-}: \\
30 \mathrm{~s}\end{array}$ & n.a. \\
\hline
\end{tabular}


Table 6. Cont.

\begin{tabular}{|c|c|c|c|c|c|c|c|c|c|c|}
\hline REF & Sensitivity & $\begin{array}{c}\text { Limit of } \\
\text { Detection }\end{array}$ & $\begin{array}{l}\text { Accuracy (Error } \\
\text { Analysis) }\end{array}$ & Selectivity & Repeatability & Reproducibility & Stability & Linearity & Response Time & $\begin{array}{c}\text { Recovery } \\
\text { Values }\end{array}$ \\
\hline Tai 2018 [33] & $\begin{array}{c}\text { Sensitivity of } \\
110 \mathrm{nA} / \mathrm{uM} \text {; } \\
\text { sensitivity of } \\
\text { correlation } \\
\text { between } \\
\text { sweat caffeine } \\
\text { concentration } \\
\text { and caffeine } \\
\text { intake of } 45 \times \\
10^{-6} \mathrm{M} / \mathrm{g}\end{array}$ & $\begin{array}{c}\mathrm{LOD} 3 \times 10^{-6} \\
\mathrm{M}\end{array}$ & $\begin{array}{c}\text { Peak current } \\
\text { variations within } \\
20 \%\end{array}$ & $\begin{array}{l}\text { The results of } \\
\text { selectivity test show } \\
\text { that the change } \\
\text { in sensor response } \\
\text { due to potential } \\
\text { interferents falls } \\
\text { within } 9.2 \% \text {. }\end{array}$ & n.a. & n.a. & n.a. & $\begin{array}{l}\text { The correlation } \\
\text { between sweat caffeine } \\
\text { concentration and } \\
\text { caffeine intake is } \\
\text { highly linear with } \\
\text { Pearson's } \\
\text { correlation coefficient } \\
\text { of } 0.98\end{array}$ & n.a. & n.a. \\
\hline $\begin{array}{c}\text { Nyein } 2018 \\
\text { [31] }\end{array}$ & $\begin{array}{c}\mathrm{Na}^{+}: 56 \\
\mathrm{mV} / \text { decade }\end{array}$ & n.a. & $\begin{array}{l}\text { Error at each flow } \\
\text { rate varies between } \\
6 \% \text { and } 11 \% \text {. No } \\
\text { accuracy data for } \\
\mathrm{Na}^{+} \text {measurements. }\end{array}$ & n.a. & n.a. & n.a. & n.a. & n.a. & $\begin{array}{l}\mathrm{Na}^{+} \text {sensor: } 12 \\
\text { min after the } \\
\text { trial begins } \\
\text { Sweat rate: } 22 \\
\text { min after the } \\
\text { trial begins }\end{array}$ & n.a. \\
\hline $\begin{array}{l}\text { Alizadeh } \\
2018[35]\end{array}$ & $\begin{array}{c}54.8 \pm 5.8 \mathrm{mV} \\
\text { per log aNa } \\
\text { per decade } \\
\mathrm{Na}^{+} \\
53.9 \pm 5.0 \mathrm{mV} \\
\text { per log aK } \\
\text { per decade } \mathrm{K}^{+}\end{array}$ & n.a. & n.a. & $\begin{array}{l}\mathrm{K}^{+} \text {ISE shows no } \\
\text { response to } \mathrm{Na}^{+} \text {ions } \\
\text { in the concentration } \\
\text { range of } 1 \times 10^{-4}-1 \\
\times 10^{-1} \mathrm{M} \text {, while its } \\
\text { sensitivity to } \\
\text { potassium } \\
\text { ions is retained in an } \\
\text { environment with } \\
\text { more than } \\
\text { onecationic species } \\
\text { present. }\end{array}$ & n.a. & n.a. & n.a. & $\begin{array}{l}\text { Linear relationship in } \\
\text { static calibration, } \mathrm{R}^{2}= \\
0.9979\end{array}$ & $\begin{array}{l}\text { Around } 15 \mathrm{~min} \\
\text { from sweat } \\
\text { induction }\end{array}$ & n.a. \\
\hline$\underset{[32]}{\operatorname{Kim} 2018}$ & n.a. & n.a. & n.a. & $\begin{array}{l}\text { Highly selective } \\
\text { response to } \\
\text { glucose/alcohol } \\
\text { concentrations in the } \\
\text { presence of relevant } \\
\text { electroactive } \\
\text { interference }\end{array}$ & $\begin{array}{c}<5 \% \text { variation } \\
\text { performing } 10 \\
\text { repetitions of } \\
\text { the same } \\
\text { measurement }\end{array}$ & n.a. & $\begin{array}{l}\text { Stability not } \\
\text { evaluated } \\
\text { during time but } \\
\text { to repetitive } \\
\text { measurements } \\
\text { performed in } \\
\text { time }(<5 \% \\
\text { variation) }\end{array}$ & $\begin{array}{l}\text { (1) Observed signal in } \\
\text { static calibration } \\
\text { resulted in a highly } \\
\text { linear response } \\
\text { (2) linear correlation } \\
\text { with } R^{2}=0.998 \\
\text { between blood and } \\
\text { sweat glucose and } R^{2} \\
=0.999 \text { blood-alcohol } \\
\text { level and } \\
\text { sweat-alcohol using } \\
\text { the same subject. }\end{array}$ & $\begin{array}{c}\text { No response } \\
\text { time evaluated: } \\
\text { waited at least } 5 \\
\text { min after the } \\
\text { analyte intake to } \\
\text { be sure to record } \\
\text { steady state } \\
\text { values }\end{array}$ & n.a. \\
\hline
\end{tabular}


Table 6. Cont.

\begin{tabular}{|c|c|c|c|c|c|c|c|c|c|c|}
\hline REF & Sensitivity & $\begin{array}{c}\text { Limit of } \\
\text { Detection }\end{array}$ & $\begin{array}{c}\text { Accuracy (Error } \\
\text { Analysis) }\end{array}$ & Selectivity & Repeatability & Reproducibility & Stability & Linearity & Response Time & $\begin{array}{c}\text { Recovery } \\
\text { Values }\end{array}$ \\
\hline $\begin{array}{c}\text { Gao } 2016 \\
{[52]}\end{array}$ & $\begin{array}{c}\text { Glu: } 2.35 \\
\mathrm{nA} / \mu \mathrm{M} \\
\mathrm{Lac}: 220 \\
\mathrm{nA} / \mathrm{mM} \\
\mathrm{Na}^{+}: 64.2 \\
\mathrm{mV} / \mathrm{dec} \\
\mathrm{K}^{+}: 61.3 \\
\mathrm{mV} / \mathrm{dec}\end{array}$ & n.a. & $\begin{array}{l}\text { Similar results } \\
\text { recorded ex situ and } \\
\text { in situ }\end{array}$ & $\begin{array}{l}\text { The presence of } \\
\text { nontarget } \\
\text { electrolytes and } \\
\text { metabolites causes } \\
\text { negligible } \\
\text { interference to the } \\
\text { response of each } \\
\text { sensor }\end{array}$ & n.a. & $\begin{array}{l}\text { RSD of } \sim 1 \% \text { in } \\
\text { sensitivity for } \\
\text { ion sensors } \\
\text { RSD of } \sim 5 \% \\
\text { in sensitivity for } \\
\text { metabolites } \\
\text { sensors. }\end{array}$ & $\begin{array}{l}\text { Metabolites } \\
\text { sensors } 5 \% \\
\text { uncertainty over } \\
4 \text { weeks. } \\
\text { Ion sensors non } \\
\text { stable, one point } \\
\text { calibration } \\
\text { required before } \\
\text { each use. }\end{array}$ & $\begin{array}{l}\text { A linear relationship } \\
\text { between } \\
\text { current/potential } \\
\text { and analyte } \\
\text { Concentrations } \\
\text { could be observed }\end{array}$ & $\begin{array}{l}\text { The responses } \\
\text { of both sensors } \\
\text { showed drift } \\
\text { initially but } \\
\text { stabilized within } \\
1 \text { min of the data } \\
\text { recording }\end{array}$ & n.a. \\
\hline $\begin{array}{l}\text { Gamella } \\
2014 \text { [38] }\end{array}$ & $\begin{array}{c}(1.6 \pm 0.1) \mathrm{A} \\
\mathrm{g}^{-1} \mathrm{~L}, \mathrm{r}= \\
0.934 \\
\text { intercept }= \\
(0.02 \pm 0.02) \mathrm{A} \\
\mathrm{g}^{-1} \mathrm{~L}(\mathrm{after} 5 \\
\text { min) }\end{array}$ & $\begin{array}{c}0.0005 \\
\text { (in vivo, } 40 \\
\text { volunteers) }\end{array}$ & n.a. & n.a. & RSD: $9.1 \%$ & RSD: $10.5 \%$ & $\begin{array}{l}30 \text { days in PBS, } \\
2 \text { months if dry } \\
\text { stored. }\end{array}$ & $\begin{array}{l}0.0005-0.6 \mathrm{~g} \mathrm{~L}^{-1} \\
\quad \text { (in vivo, } 40 \\
\text { volunteers) }\end{array}$ & $\begin{array}{l}\text { Baseline: in 2-6 } \\
\text { min. signal } \\
\text { appearance: } 2-5 \\
\text { s. Steady state: } \\
2-4 \text { min } \\
\text { (depends on } \\
\text { ethanol content) }\end{array}$ & n.a. \\
\hline
\end{tabular}




\section{Conclusions}

The present work revised and discussed the main validation procedures and standards for the assessment of mobile or wearable PoCT devices, specifically focusing on sweat analysis. The metrological aspects highlighted showed that recent years have brought much attention to making those devices more reliable. However, a further effort is still needed in order to standardize the procedure that should be used in validating stand-alone electronic platforms based on electrochemical biosensors; only by having common and shared guidelines, will it be possible to enable the reliable use and commercialization of such systems for multiple biomarker detection in wearable devices.

Author Contributions: Conceptualization, S.T., N.F.L., M.B. and G.A.; writing-original draft preparation, S.T., M.B. and G.A.; writing-review and editing, N.F.L., M.S. and E.S. All authors have read and agreed to the published version of the manuscript.

Funding: This research received no external funding.

Institutional Review Board Statement: Not applicable.

Informed Consent Statement: Not applicable.

Conflicts of Interest: The authors declare no conflict of interest.

\section{References}

1. Sardini, E.; Serpelloni, M.; Tonello, S. Printed electrochemical biosensors: Opportunities and metrological challenges. Biosensors 2020, 10, 11. [CrossRef] [PubMed]

2. Criscuolo, F.; Hanitra, I.N.; Aiassa, S.; Taurino, I.; Oliva, N.; Carrara, S.; De Micheli, G. Wearable multifunctional sweat-sensing system for efficient healthcare monitoring. Sens. Actuators B Chem. 2021, 328, 129017. [CrossRef]

3. Shrivastava, S.; Trung, T.Q.; Lee, N.-E. Recent progress, challenges, and prospects of fully integrated mobile and wearable point-of-care testing systems for self-testing. Chem. Soc. Rev. 2020, 49, 1812-1866. [CrossRef] [PubMed]

4. Tyler, J.; Choi, S.W.; Tewari, M. Real-time, personalized medicine through wearable sensors and dynamic predictive modeling: A new paradigm for clinical medicine. Curr. Opin. Syst. Biol. 2020, 20, 17-25. [CrossRef] [PubMed]

5. Islam, T.; Mukhopadhayay, S.C. Wearable sensors for physiological parameters measurement: Physics, characteristics, design and applications. In Wearable Sensors: Applications Design and Implementation; IOP Publishing: Bristol, UK, 2017 ; pp. 1-31.

6. Tonello, S.; Serpelloni, M.; Lopomo, N.F.; Sardini, E.; Abate, G.; Uberti, D.L. Preliminary study of a low-cost point-of-care testing system using screen-printed biosensors: For early biomarkers detection related to Alzheimer Disease. In Proceedings of the IEEE International Symposium on Medical Measurements and Applications (MeMeA), Benevento, Italy, 15-18 May 2016; pp. 1-6.

7. Rezabakhsh, A.; Rahbarghazi, R.; Fathi, F. Surface plasmon resonance biosensors for detection of Alzheimer's biomarkers; an effective step in early and accurate diagnosis. Biosens. Bioelectron. 2020, 167, 112511. [CrossRef]

8. Sharma, S.; Kumari, R.; Varshney, S.K.; Lahiri, B. Optical biosensing with electromagnetic nanostructures. Rev. Phys. 2020, 5, 100044. [CrossRef]

9. Méjard, R.; Griesser, H.J.; Thierry, B. Optical biosensing for label-free cellular studies. TrAC Trends Anal. Chem. 2014, 53, 178-186. [CrossRef]

10. Yu, H.L.L.; Maslova, A.; Hsing, I.-M. Rational design of electrochemical DNA biosensors for point-of-care applications. ChemElectroChem 2017, 4, 795-805. [CrossRef]

11. Kanitthamniyom, P.; Zhou, A.; Feng, S.; Liu, A.; Vasoo, S.; Zhang, Y. A 3D-printed modular magnetic digital microfluidic architecture for on-demand bioanalysis. Microsyst. Nanoeng. 2020, 6, 1. [CrossRef]

12. Solhi, E.; Hasanzadeh, M.; Babai, P. Electrochemical paper-based analytical devices (ePADs) toward biosensing: Recent advances and challenges in bioanalysis. Anal. Methods 2020, 12, 1398-1414. [CrossRef]

13. Kit-Anan, W.; Olarnwanich, A.; Sriprachuabwong, C.; Karuwan, C.; Tuantranont, A.; Wisitsoraat, A.; Srituravanich, W.; Pimpin, A. Disposable paper-based electrochemical sensor utilizing inkjet-printed Polyaniline modified screen-printed carbon electrode for Ascorbic acid detection. J. Electroanal. Chem. 2012, 685, 72-78. [CrossRef]

14. Tonello, S.; Lopomo, N.F.; Serpelloni, M.; Serzanti, M.; Dell'Era, P.; Sardini, E. Preliminary study of inkjet printed sensors for monitoring cell cultures. Procedia Eng. 2016, 168, 578-581. [CrossRef]

15. Tonello, S.; Stradolini, F.; Abate, G.; Uberti, D.; Serpelloni, M.; Carrara, S.; Sardini, E. Electrochemical detection of different p53 conformations by using nanostructured surfaces. Sci. Rep. 2019, 9, 17347. [CrossRef]

16. Han, Y.; Dong, J. Electrohydrodynamic printing for advanced micro/nanomanufacturing: Current progresses, opportunities, and challenges. J. Micro Nano-Manuf. 2018, 6, 4. [CrossRef]

17. Menon, S.; Mathew, M.R.; Sam, S.; Keerthi, K.; Kumar, K.G. Recent advances and challenges in electrochemical biosensors for emerging and re-emerging infectious diseases. J. Electroanal. Chem. 2020, 878, 114596. [CrossRef] 
18. Lee, H.; Song, C.; Hong, Y.S.; Kim, M.S.; Cho, H.R.; Kang, T.; Shin, K.; Choi, S.H.; Hyeon, T.; Kim, D.-H. Wearable/disposable sweat-based glucose monitoring device with multistage transdermal drug delivery module. Sci. Adv. 2022, 3, e1601314. [CrossRef] [PubMed]

19. Cinti, S.; de Lellis, B.; Moscone, D.; Arduini, F. Sustainable monitoring of Zn(II) in biological fluids using office paper. Sens. Actuators B Chem. 2017, 253, 1199-1206. [CrossRef]

20. Sun, A.; Venkatesh, A.G.; Hall, D.A. A multi-technique reconfigurable electrochemical biosensor: Enabling personal health monitoring in mobile devices. IEEE Trans. Biomed. Circuits Syst. 2016, 10, 945-954. [CrossRef]

21. Zhang, M.; Guo, S.; Weller, D.; Hao, Y.; Wang, X.; Ding, C.; Chai, K.; Zou, B.; Liu, R. CdSSe nanowire-chip based wearable sweat sensor. J. Nanobiotechnol. 2019, 17, 42. [CrossRef] [PubMed]

22. Anastasova, S.; Crewther, B.; Bembnowicz, P.; Curto, V.; Ip, H.M.; Rosa, B.; Yang, G. Zwearable multisensing patch for continuous sweat monitoring. Biosens. Bioelectron. 2017, 93, 139-145. [CrossRef] [PubMed]

23. Martín, A.; Kim, J.; Kurniawan, J.F.; Sempionatto, J.R.; Moreto, J.R.; Tang, G.; Campbell, A.C.; Shin, A.; Lee, M.Y.; Liu, X.; et al. Epidermal microfluidic electrochemical detection system: Enhanced sweat sampling and metabolite detection. ACS Sens. 2017, 2, 1860-1868. [CrossRef]

24. Currano, L.J.; Sage, F.C.; Hagedon, M.; Hamilton, L.; Patrone, J.; Gerasopoulos, K. Wearable sensor system for detection of lactate in sweat. Sci. Rep. 2018, 8, 15890. [CrossRef] [PubMed]

25. Garcia, S.O.; Ulyanova, Y.V.; Figueroa-Teran, R.; Bhatt, K.H.; Singhal, S.; Atanassov, P. Wearable sensor system powered by a biofuel cell for detection of lactate levels in sweat. ECS J. Solid State Sci. Technol. 2016, 5, M3075-M3081. [CrossRef]

26. Ouzzani, M.; Hammady, H.; Fedorowicz, Z.; Elmagarmid, A. Rayyan-A web and mobile app for systematic reviews. Syst. Rev. 2016, 5, 210. [CrossRef]

27. Lavín, Á.; Vicente, J.D.; Holgado, M.; Laguna, M.F.; Casquel, R.; Santamaría, B.; Maiger, M.V.; Hernandez, A.L.; Ramirez, Y. On the determination of uncertainty and limit of detection in label-free biosensors. Sensors 2018, 18, 7. [CrossRef] [PubMed]

28. Armbruster, D.A.; Pry, T. Limit of blank, limit of detection and limit of quantitation. Clin. Biochem. Rev. 2008, 29, S49-S52.

29. Xu, G.; Cheng, C.; Yuan, W.; Liu, Z.; Zhu, L.; Li, X.; Lu, Y.; Chen, Z.; Liu, J.; Cui, Z.; et al. Smartphone-based battery-free and flexible electrochemical patch for calcium and chloride ions detections in biofluids. Sens. Actuators B Chem. 2019, $297,126743$. [CrossRef]

30. Gauglitz, G. Analytical evaluation of sensor measurements. Anal. Bioanal. Chem. 2018, 410, 5-13. [CrossRef] [PubMed]

31. Nyein, H.Y.Y.; Tai, L.C.; Ngo, Q.P.; Chao, M.; Zhang, G.B.; Gao, W.A.; Bariya, M.; Billock, J.; Kim, H.; Fahad, H.H.; et al. Wearable microfluidic sensing patch for dynamic sweat secretion analysis. ACS Sens. 2018, 3, 944-952. [CrossRef]

32. Kim, J.; Sempionatto, J.R.; Imani, S.; Hartel, M.C.; Barfidokht, A.; Tang, G.; Campbell, A.S.; Mercier, P.P.; Wang, J. Simultaneous monitoring of sweat and interstitial fluid using a single wearable biosensor platform. Adv. Sci. 2018, 5, 1800880. [CrossRef]

33. Tai, L.C.; Gao, W.; Chao, M.; Bariya, M.; Ngo, Q.P.; Shahpar, Z.; Hnin, Y.Y.N.; Park, H.; Sun, J.; Jung, Y.; et al. Methylxanthine drug monitoring with wearable sweat sensors. Adv. Mater. 2018, 30, 1707442. [CrossRef] [PubMed]

34. Zhang, J.; Rupakula, M.; Bellando, F.; Garcia Cordero, E.; Longo, J.; Wildhaber, F.; Hermet, G.; Guerin, H.; Ionescu, A.M. Sweat biomarker sensor incorporating picowatt, three-dimensional extended metal gate ion sensitive field effect transistors. ACS Sens. 2019, 4, 2039-2047. [CrossRef] [PubMed]

35. Alizadeh, A.; Burns, A.; Lenigk, R.; Gettings, R.; Ashe, J.; Porter, A.; McCaul, M.; Berrett, R.; Diamond, D.; White, P.; et al. Wearable patch for continuous monitoring of sweat electrolytes during exertion. Lab. Chip 2018, 18, 2632-2641. [CrossRef] [PubMed]

36. Ang, L.F.; Por, L.Y.; Yam, M.F. Study on different molecular weights of chitosan as an immobilization matrix for a glucose biosensor. PLoS ONE 2013, 8, e70597. [CrossRef] [PubMed]

37. Karnes, H.T.; Shiu, G.; Shah, V. Validation of bioanalytical methods. Pharm. Res. 1991, 8, 421-426. [CrossRef]

38. Gamella, M.; Campuzano, S.; Manso, J.; de Rivera, G.G.; López-Colino, F.; Reviejo, A.J.; Pingarron, J.M. A novel non-invasive electrochemical biosensing device for in situ determination of the alcohol content in blood by monitoring ethanol in sweat. Anal. Chim. Acta 2014, 806, 1-7. [CrossRef] [PubMed]

39. Gibson, T. Biosensors: The stability problem. Analysis 1999, 27, 630-638. [CrossRef]

40. Andreasson, U.; Perret-Liaudet, A.; van Waalwijk van Doorn, L.J.; Blennow, K.; Chiasserini, D.; Engelborghs, S.; Fladby, T.; Genc, S.; Kruse, N.; Kuiperij, H.B. A practical guide to immunoassay method validation. Front. Neurol. 2015, 6, 179. [CrossRef] [PubMed]

41. Suydam, L.A.; Rulis, A.M. Guidance for industry. Bioanalytical method validation. Fed. Regist. 2001, 66, $28526-28527$.

42. Vinoth, R.; Nakagawa, T.; Mathiyarasu, J.; Mohan, A.M.V. Fully printed wearable microfluidic devices for high-throughput sweat sampling and multiplexed electrochemical analysis. ACS Sens. 2021, 6, 1174-1186. [CrossRef]

43. Zhang, S.; Zahed, M.A.; Sharifuzzaman, M.; Yoon, S.; Hui, X.; Barman, S.C.; Sharma, S.; Yoon, H.Y.; Park, C.; Park, J.Y. A wearable battery-free wireless and skin-interfaced microfluidics integrated electrochemical sensing patch for on-site biomarkers monitoring in human perspiration. Biosens. Bioelectron. 2021, 175, 112844. [CrossRef] [PubMed]

44. He, W.; Wang, C.; Wang, H.; Jian, M.; Lu, W.; Liang, X.; Zhang, X.; Yang, F.; Zhang, Y. Integrated textile sensor patch for real-time and multiplex sweat analysis. Sci. Adv. 2019, 5, eaax0649. [CrossRef] [PubMed] 
45. Bandodkar, A.J.; Gutruf, P.; Choi, J.; Lee, K.; Sekine, Y.; Reeder, J.T.; Jeang, W.J.; Aranyosi, A.J.; Lee, S.P.; Model, J.B.; et al. Battery-free, skin-interfaced microfluidic/electronic systems for simultaneous electrochemical, colorimetric, and volumetric analysis of sweat. Sci. Adv. 2019, 5, eaav3294. [CrossRef]

46. Moonen, E.; Haakma, J.; Peri, E.; Pelssers, E.; Mischi, M.; Toonder, J. Wearable sweat sensing for prolonged, semicontinuous, and nonobtrusive health monitoring. View 2020, 1, 20200077. [CrossRef]

47. Lu, Y.; Jiang, K.; Chen, D.; Shen, G. Wearable sweat monitoring system with integrated micro-supercapacitors. Nano Energy 2019, 58, 624-632. [CrossRef]

48. Martin, A.; García-Carmona, L.; Barfidokht, A.; Kurniawan, J.F.; Moreto, J.R.; Tang, G.; Shin, A.; Liu, X.; Escarpa, A.; Wnag, J. Skin-worn soft microfluidic potentiometric detection system. Electroanalysis 2019, 31, 239-245.

49. Liang, B.; Cao, Q.; Mao, X.; Pan, W.; Tu, T.; Fang, L.; Ye, X. An integrated paper-based microfluidic device for real-time sweat potassium monitoring. IEEE Sens. J. 2021, 21, 9642-9648. [CrossRef]

50. Purohit, B.; Vernekar, R.; Shetti, N.; Chandra, P. Biosensor nanoengineering: Design, operation, and implementation for biomolecular analysis. Sens. Int. 2020, 1, 100040. [CrossRef]

51. Migliozzi, D.; Guibentif, T. Assessing the Potential deployment of biosensors for point-of-care diagnostics in developing countries: Technological, economic and regulatory aspects. Biosensors 2018, 8, 119. [CrossRef] [PubMed]

52. Gao, W.; Emaminejad, S.; Nyein HY, Y.; Challa, S.; Chen, K.; Peck, A.; Fahad, H.M.; Ota, H.; Shiraki, H.; Kiriya, D.; et al. Fully integrated wearable sensor arrays for multiplexed in situ perspiration analysis. Nature 2016, 529, 509-514. [CrossRef]

53. May, E.E.; Harper, J.C.; Brozik, S.M. Computational biosensors: Molecules, algorithms, and detection platforms. Model. Methodol. Tools Mol. Nano-Scale Commun. 2016, 9, 541-577. 